\title{
Temperature requirements for growth and survival of macroalgae from Disko Island (Greenland)
}

\author{
B. Bischoff \& C. Wiencke \\ Institute for Polar and Marine Research; Am Handelshafen 12, D-27570 Bremerhaven, \\ Federal Republic of Germany
}

\begin{abstract}
The temperature requirements for growth and upper temperature tolerance were determined in 16 macroalgal species collected on Disko Island (Greenland). The upper survival temperatures were examined in $1^{\circ} \mathrm{C}$ steps, and growth measured at $5^{\circ} \mathrm{C}$ intervals between 0 and $20^{\circ} \mathrm{C}$ using a refined method, where the fresh weight was determined weekly or fortnightly over a period of 5 or 6 weeks. To express temperature-growth responses, growth rates of temperatureacclimated plants were taken. Two groups with different temperature requirements were identified: (1) A stenothermal group including Acrosiphonia arcta, Acrosiphonia sonderi, Urospora penicilliformis, Devaleraea ramentacea, Desmarestia aculeata, Pilayella littoralis, growing between 0 and (10 to) 15 (or 20$)^{\circ} \mathrm{C}$ with optima between 0 and $10^{\circ} \mathrm{C}$. The upper survival temperatures in these species and in Chromastrum secundatum, Chromastrum virgatulum, Chordaria flagelliformis were between 17 and $23^{\circ} \mathrm{C}$ (duration of experiment: 2 weeks). (2) A eurythermal group including Enteromorpha clathrata, Enteromorpha intestinalis and Polysiphonia urceolata growing between 0 and $20^{\circ} \mathrm{C}$ with growth optima at 10 or $15^{\circ} \mathrm{C}$. The upper survival temperatures in these species and in Chaetomorpha tortuosa, Bangia atropurpurea and Eudesme virescens were between 24 and $31^{\circ} \mathrm{C}$. These algal species showed little adaptation to the Arctic temperatures. In contrast, algae from the first group exhibited a relatively high adaptation to low temperatures - approaching the low temperature requirements of Antarctic algae. The results are discussed in relation to the geographic distribution of individual species.
\end{abstract}

\section{INTRODUCTION}

The development of the cold-water marine algal floras in the Northern and Southern Hemisphere are a result of the great glaciations since the Tertiary (Lüning \& tom Dieck, 1989). A characteristic cold water environment has existed in Antarctica for 25-30 million years ( = 25-30 Ma), a first glacial peak occurring at approx. 14 Ma (Grant-Meckie, 1979). This development began much later in the North Polar Sea, at approx. $2 \mathrm{Ma}$ (Thiede, 1986). The four great Pleistocene glaciations displaced the terrestial and marine flora and fauna in the Northern Hemisphere towards the south, and during the interglacials, again towards the north. 18,000 years ago, during the last glaciation maximum (Würm-/ Wisconsin), the temperature of the upper seawater layer in the North Atlantic was ca. $10^{\circ} \mathrm{C}$ lower than today (Lüning, 1990). During the glaciations, the North Atlantic region (northwards of a line from New York to southern England) was covered with an ice-layer and was re-colonised during the interglaciation (postglacial colonisation, Hempel, 1987). It is therefore assumed that the Arctic region is an extension of the cold-temperate region of the North Atlantic (Lüning, 1990). 
Because of the earlier glaciation of Antarctica, there was a longer period available for the development of cold-water biota in the Southern Ocean, compared to that in the Northern Hemisphere (Hempel, 1987; Lüning \& tom Dieck, 1989). Hence, a stenothermal flora and fauna developed in the Antarctica, with a high growth efficiency at low temperatures and a correspondingly low tolerance to high temperatures (Hempel, 1987; Wiencke \& tom Dieck, 1989, 1990). In contrast, Arctic and cold-temperate species from the Northern Hemisphere are relatively eurythermal (Bolton \& Lüning, 1982; Bolton, 1983; Egan et al., 1990; tom Dieck, 1989, 1992b, 1993).

Experimental data on temperature requirements of Arctic macroalgae are rare (Breeman, 1988). In this study, the temperature requirements for growth and survival of Arctic macroalgae from Disko Island, Greenland, were determined. The method for determination of growth rates at different temperatures has been refined, and, using this technique, it was possible to demonstrate a higher acclimation potential, as well as adaptation to the Arctic temperature regime, than was previously recorded. These results are discussed in relation to the temperature requirements of the same or other species from cold-temperate regions and from the Southern Ocean. Finally, the temperature data obtained are used to explain the biogeographic boundaries of the investigated species.

\section{MATERIALS AND METHODS}

The macroalgae investigated were isolated as spores or thallus fragments by $\mathrm{C}$. Wiencke during an expedition to Disko Island (Greenland), using the methods described by Clayton \& Wiencke (1986). The species are listed in Table 1. Algae were subsequently cultivated in the laboratory at a temperature of $10^{\circ} \mathrm{C}$. Cultivation methods, determination of growth rates and upper survival temperatures (duration of experiments: 2 weeks) were carried out as described by Wiencke \& tom Dieck (1989). The growth experiments, however, were partly modified; growth was followed over a period of 5 weeks. Fresh weight was measured weekly or fortnightly and the algal biomass was reduced to initial weight, in order to exclude the effects of low light conditions resulting from self-shading. Between repetitive experiments the same initial weight was taken. For each interval, the specific growth rates, expressed in $\%$ increase $\mathrm{d}^{-1}$, were calculated by use of the following equation from Lüning (1985):

$$
\text { Specific growth rate }=100\left(\operatorname{In} \mathrm{W}_{\mathrm{t}} / \mathrm{In} \mathrm{W}_{\mathrm{j}}\right) \mathrm{t}^{-1} \text {; }
$$

where $W_{j}=$ initial size or fresh weight; $W_{t}=$ size or fresh weight on day $t_{i} t=$ time interval.

In Devaleraea ramentacea and in the sporophytes of Desmarestia aculeata growth was determined once during a period of 6 weeks. In $D$. aculeata gametophytes growth was investigated over a period of 3 days, following 5 days where the algae had been maintained at the experimental temperature and light conditions. The experimental period could not be extended, because of the high growth rates (Fig.6), making a planimetric evaluation impossible.

\section{RESULTS}

The change of growth rates in Acrosiphonia sonderi with time after exposure to various temperatures is shown in Figures 1a-e. During the second week the growth rates 
Table 1. Investigated species, location, isolator and culture-number

\begin{tabular}{|c|c|c|c|}
\hline Algal species & Location & $\begin{array}{l}\text { Isolator/ } \\
\text { Cultivator }\end{array}$ & $\begin{array}{l}\text { Culture } \\
\text { No. }\end{array}$ \\
\hline \multicolumn{4}{|l|}{ Chlorophyta } \\
\hline $\begin{array}{l}\text { Acrosiphonia arcta (Dillw.) J. Ag. } \\
\text { Acrosiphonales }\end{array}$ & $\begin{array}{l}\text { Disko Island, } \\
\text { Nipisat }\end{array}$ & $\begin{array}{l}\text { Pedersen/ } \\
\text { Wiencke/ } \\
\text { Bischoff }\end{array}$ & 1120 \\
\hline $\begin{array}{l}\text { Acrosiphonia sonderi (Kütz.) Kornm. } \\
\text { Acrosiphonales }\end{array}$ & $\begin{array}{l}\text { Disko Island, } \\
\text { Godhavn }\end{array}$ & $\begin{array}{l}\text { Wiencke/ } \\
\text { Bischoff }\end{array}$ & 1096 \\
\hline $\begin{array}{l}\text { Urospora penicilliformis Roth (Areschoug) } \\
\text { Acrosiphonales }\end{array}$ & $\begin{array}{l}\text { Disko Island, } \\
\text { Godhavn }\end{array}$ & $\begin{array}{l}\text { Wiencke/ } \\
\text { Bischoff }\end{array}$ & 1104 \\
\hline $\begin{array}{l}\text { Chaetomorpha tortuosa (Dillw.) Kütz. } \\
\text { Cladophorales }\end{array}$ & $\begin{array}{l}\text { Disko Island, } \\
\text { Godhavn }\end{array}$ & $\begin{array}{l}\text { Wiencke/ } \\
\text { Bischoff }\end{array}$ & 1091 \\
\hline $\begin{array}{l}\text { Enteromorpha clathrata (Roth) Grev. } \\
\text { Ulvales }\end{array}$ & $\begin{array}{l}\text { Disko Island, } \\
\text { Godhavn }\end{array}$ & $\begin{array}{l}\text { Wiencke/ } \\
\text { Bischoff }\end{array}$ & 1086 \\
\hline $\begin{array}{l}\text { Enteromorpha intestinalis (L.) Link } \\
\text { Ulvales }\end{array}$ & $\begin{array}{l}\text { Disko Island, } \\
\text { Godhavn }\end{array}$ & $\begin{array}{l}\text { Wiencke/ } \\
\text { Bischoff }\end{array}$ & 1088 \\
\hline $\begin{array}{l}\text { Unva lactuca } L \text {. } \\
\text { Ulvales }\end{array}$ & $\begin{array}{l}\text { Disko Island, } \\
\text { Godhavn }\end{array}$ & $\begin{array}{l}\text { Wiencke/ } \\
\text { Bischoff }\end{array}$ & 1128 \\
\hline \multicolumn{4}{|l|}{ Rhodophyta } \\
\hline $\begin{array}{l}\text { Bangia atropurpurea (Roth) C. Ag. } \\
\text { Bangiales }\end{array}$ & $\begin{array}{l}\text { Disko Island, } \\
\text { Godhavn }\end{array}$ & $\begin{array}{l}\text { Wiencke/ } \\
\text { Bischoff }\end{array}$ & 2089 \\
\hline $\begin{array}{l}\text { Devaleraea ramentacea (L.) Guiry } \\
\text { male gametophyte, Palmariales }\end{array}$ & $\begin{array}{l}\text { Disko Island, } \\
\text { Godhavn }\end{array}$ & $\begin{array}{l}\text { Wiencke/ } \\
\text { Bischoff }\end{array}$ & 2094 \\
\hline $\begin{array}{l}\text { Polysiphonia urceolata (Lightf. ex Diliw.) Grev. } \\
\text { Ceramiales }\end{array}$ & $\begin{array}{l}\text { Disko Island, } \\
\text { Godhavn }\end{array}$ & $\begin{array}{l}\text { Wiencke/ } \\
\text { Bischoff }\end{array}$ & 2093 \\
\hline $\begin{array}{l}\text { Chromastrum secundatum (Lyngb.) Papenfuss } \\
\text { Nemaliales }\end{array}$ & $\begin{array}{l}\text { Disko Island, } \\
\text { Godhavn }\end{array}$ & $\begin{array}{l}\text { Wiencke/ } \\
\text { Bischoff }\end{array}$ & 2092 \\
\hline $\begin{array}{l}\text { Chromastrum virgatulum (Harvey) Papenfuss } \\
\text { Nemaliales }\end{array}$ & $\begin{array}{l}\text { Disko Island, } \\
\text { Nipisat }\end{array}$ & $\begin{array}{l}\text { Pedersen/ } \\
\text { Wiencke/ } \\
\text { Bischoff }\end{array}$ & 2091 \\
\hline \multicolumn{4}{|l|}{ Phaeophyta } \\
\hline $\begin{array}{l}\text { Chordaria flagelliformis (O. F. Müller) C. Ag. } \\
\text { Chordariales }\end{array}$ & $\begin{array}{l}\text { Disko Island, } \\
\text { Godhavn }\end{array}$ & $\begin{array}{l}\text { Wiencke/ } \\
\text { Bischoff }\end{array}$ & \\
\hline $\begin{array}{l}\text { Eudesme virescens (Carm. ex. Harv. Hook) J. Ag. } \\
\text { Chordariales }\end{array}$ & $\begin{array}{l}\text { Disko Island, } \\
\text { Godhavn }\end{array}$ & $\begin{array}{l}\text { Wiencke/ } \\
\text { Bischoff }\end{array}$ & 3107 \\
\hline $\begin{array}{l}\text { Desmarestia aculeata (L.) Lamour. } \\
\text { male \& female gametophyte, Desmarestiales }\end{array}$ & $\begin{array}{l}\text { Disko Island, } \\
\text { Godhavn }\end{array}$ & $\begin{array}{l}\text { Wiencke/ } \\
\text { Bischoff }\end{array}$ & $\begin{array}{l}3108 / \\
3109\end{array}$ \\
\hline $\begin{array}{l}\text { Pilayella littoralis (L.) Kjellm. } \\
\text { Ectocarpales }\end{array}$ & $\begin{array}{l}\text { Disko Island, } \\
\text { Godhavn }\end{array}$ & $\begin{array}{l}\text { Wiencke/ } \\
\text { Bischoff }\end{array}$ & 3100 \\
\hline
\end{tabular}

at 0 and $5^{\circ} \mathrm{C}$ increased rapidly, levelling off during the next 7 days and increasing slowly up to the end of experiment. At 10 and $15^{\circ} \mathrm{C}$, similar but not as large increases in growth rate were evident, and, later, growth rates were relatively constant. At $20^{\circ} \mathrm{C}$, growth rates decreased during the second week, but then increased slowly. 

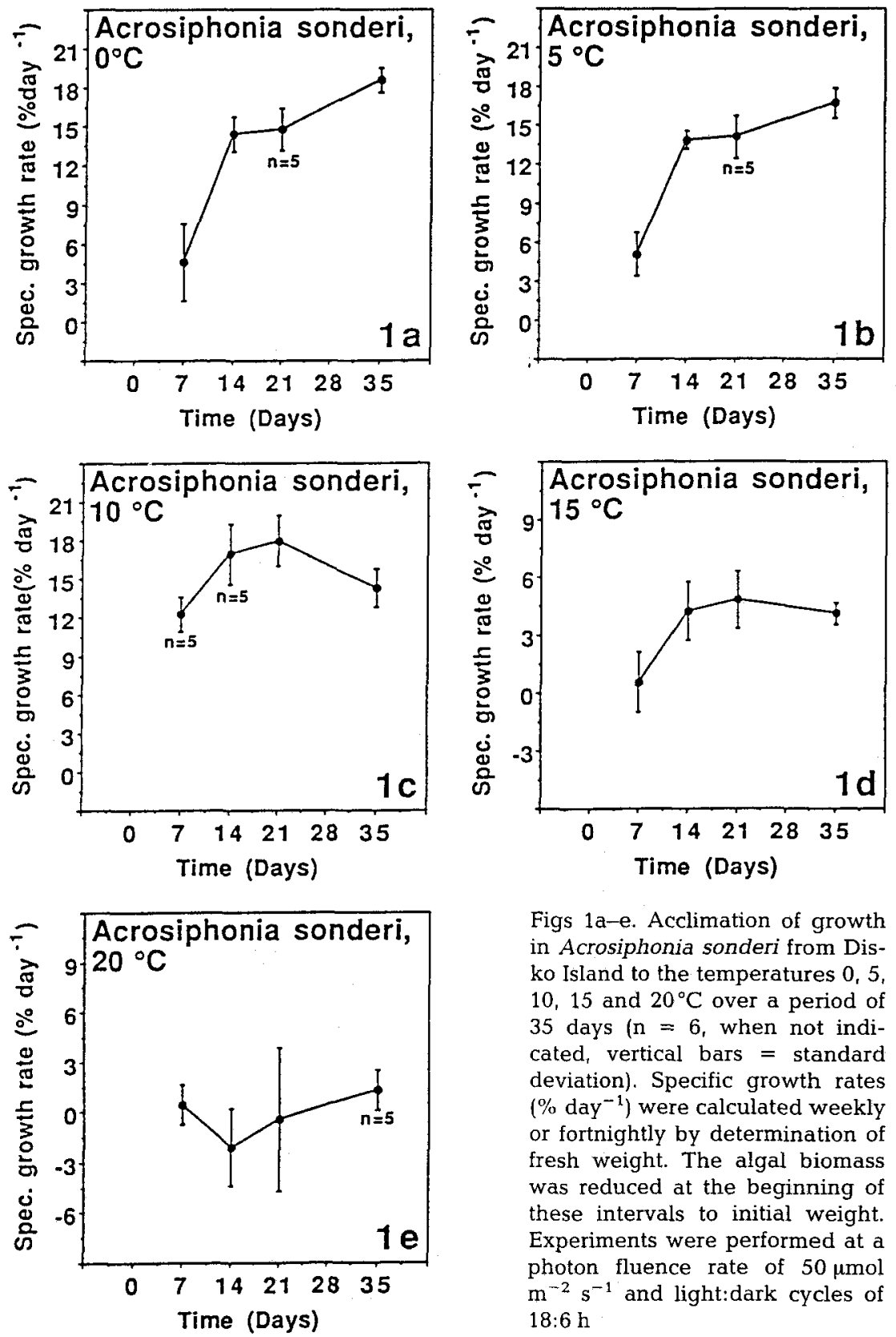

Figs 1a-e. Acclimation of growth in Acrosiphonia sonderi from Disko Island to the temperatures 0,5 , 10,15 and $20^{\circ} \mathrm{C}$ over a period of 35 days $(n=6$, when not indicated, vertical bars $=$ standard deviation). Specific growth rates $\left(\%\right.$ day $\left.^{-1}\right)$ were calculated weekly or fortnightly by determination of fresh weight. The algal biomass was reduced at the beginning of these intervals to initial weight. Experiments were performed at a photon fluence rate of $50 \mu \mathrm{mol}$ $\mathrm{m}^{-2} \mathrm{~s}^{-1}$ and light:dark cycles of $18: 6 \mathrm{~h}$

The investigated species can be classified into 2 groups according to their temperature-growth characteristics (Figs. 2-12) and upper survival temperature (USL):

G r o u p 1, stenothermal species: Acrosiphonia sonderi grew between 0 and $20^{\circ} \mathrm{C}$, with an optimum at $0^{\circ} \mathrm{C}$ and with very low rates at $\geq 15^{\circ} \mathrm{C}$ (Fig. 2). The USL was $23^{\circ} \mathrm{C}$ 
Table 2. Life cycles of the investigated marcroalgae

\begin{tabular}{|c|c|c|}
\hline Algal species & Life-cycle & Literature \\
\hline \multicolumn{3}{|l|}{ Chlorophyta } \\
\hline $\begin{array}{l}\text { Acrosiphonia arcta (Dillw.) J. Ag. } \\
\text { Acrosiphonales }\end{array}$ & $\begin{array}{l}\text { isomorphic, } \\
\text { monoecious }\end{array}$ & Kornmann (1964) \\
\hline $\begin{array}{l}\text { Acrosiphonia sonderi (Kütz.) Kornm. } \\
\text { Acrosiphonales }\end{array}$ & asexual & Kornmann \& Sahling (1983) \\
\hline $\begin{array}{l}\text { Urospora penicilliformis Roth (Areschoug) } \\
\text { Acrosiphonales }\end{array}$ & $\begin{array}{l}\text { heteromorphic, } \\
\text { dioecious, } \\
\text { anisogameous }\end{array}$ & $\begin{array}{l}\text { Lokhorst \& Trask (1981) } \\
\text { Kornmann }(1966 \mathrm{a}, \mathrm{b})\end{array}$ \\
\hline $\begin{array}{l}\text { Chaetomorpha tortuosa (Dillw.) Kütz } \\
\text { Cladophorales }\end{array}$ & asexual & Kormmann (1972) \\
\hline $\begin{array}{l}\text { Enteromorpha clathrata (Roth) Grev. } \\
\text { Ulvales }\end{array}$ & $\begin{array}{l}\text { isomorphic, dioecious, } \\
\text { anisogameous }\end{array}$ & Bliding (1963) \\
\hline $\begin{array}{l}\text { Enteromorpha intestinalis (L.) Link } \\
\text { Ulvales }\end{array}$ & $\begin{array}{l}\text { isomorphic, dioecious, } \\
\text { anisogameous }\end{array}$ & Bliding (1963) \\
\hline $\begin{array}{l}\text { Ulva lactuca L. } \\
\text { Ulvales }\end{array}$ & $\begin{array}{l}\text { isomorphic, dioecious, } \\
\text { anisogameous }\end{array}$ & Kornmann \& Sahling (1983) \\
\hline \multicolumn{3}{|l|}{ Rhodophyta } \\
\hline $\begin{array}{l}\text { Bangia atropurpurea (Roth) C. Ag. } \\
\text { Bangiales }\end{array}$ & $\begin{array}{l}\text { asexual, } \\
\text { heteromorphic }\end{array}$ & $\begin{array}{l}\text { Pedersen (1976) } \\
\text { Richardson \& Dixon (1968) }\end{array}$ \\
\hline $\begin{array}{l}\text { Devaleraea ramentacea (L.) Guiry } \\
\text { Palmariales }\end{array}$ & $\begin{array}{l}\text { heteromorphic, } \\
\text { dioecious }\end{array}$ & van der Meer (1981) \\
\hline $\begin{array}{l}\text { Polysiphonia urceolata (Lightf. ex Dillw.) Grev. } \\
\text { Ceramiales }\end{array}$ & isomorphic, dioecious & van den Hoek (1984) \\
\hline $\begin{array}{l}\text { Chromastrum secundatum (Lyngb) Papenfuss } \\
\text { Nemaliales }\end{array}$ & asexual & Pedersen (1976) \\
\hline $\begin{array}{l}\text { Chromastrum virgatulum (Harvey) Papenfuss } \\
\text { Nemaliales }\end{array}$ & asexual & Pedersen (1976) \\
\hline \multicolumn{3}{|l|}{ Phaeophyta } \\
\hline $\begin{array}{l}\text { Chordaria flagelliformis (O. F. Müller) C. Ag. } \\
\text { Chordariales }\end{array}$ & $\begin{array}{l}\text { asexual, } \\
\text { heteromorphic }\end{array}$ & Kornmann (1962) \\
\hline $\begin{array}{l}\text { Eudesme virescens (Carm. ex. Harv. Hook) J. Ag. } \\
\text { Chordariales }\end{array}$ & $\begin{array}{l}\text { asexual, } \\
\text { heteromorphic }\end{array}$ & Peters (1987) \\
\hline $\begin{array}{l}\text { Desmarestia aculeata (L.) Lamour., } \\
\text { Desmarestiales }\end{array}$ & $\begin{array}{l}\text { heteromorphic, } \\
\text { dioecious, } \\
\text { oogameous }\end{array}$ & $\begin{array}{l}\text { Schreiber (1932) } \\
\text { Müller \& Lüthe (1981) }\end{array}$ \\
\hline $\begin{array}{l}\text { Pilayella littoralis (L.) Kjellm. } \\
\text { Ectocarpales }\end{array}$ & asexual & Müller \& Stache (1989) \\
\hline
\end{tabular}

(Table 3). Macrothalli of Acrosiphonia arcta and Urospora penicilliformis grew between 0 and $15^{\circ} \mathrm{C}$, with optimum growth at 0 to $10^{\circ} \mathrm{C}$ and $0^{\circ} \mathrm{C}$, respectively (Fig. 4). Very low growth rates were measured in $A$. arcta at $\geq 15^{\circ} \mathrm{C}$ (Fig. 3). A. arcta survived up to $22^{\circ} \mathrm{C}$ and $U$. penicilliformis up to $23^{\circ} \mathrm{C}$ (Table 3). The male gametophyte of Devaleraea ramentacea grew at similar rates between 0 and $10^{\circ} \mathrm{C}$ with a slight optimum at $5{ }^{\circ} \mathrm{C}$ (Fig. 5). The USL was $19^{\circ} \mathrm{C}$ (Table 3). The gametophytes of Desmarestia aculeata grew between 0 and $20^{\circ} \mathrm{C}$ (Fig. 6). The female gametophyte exhibited a growth plateau 

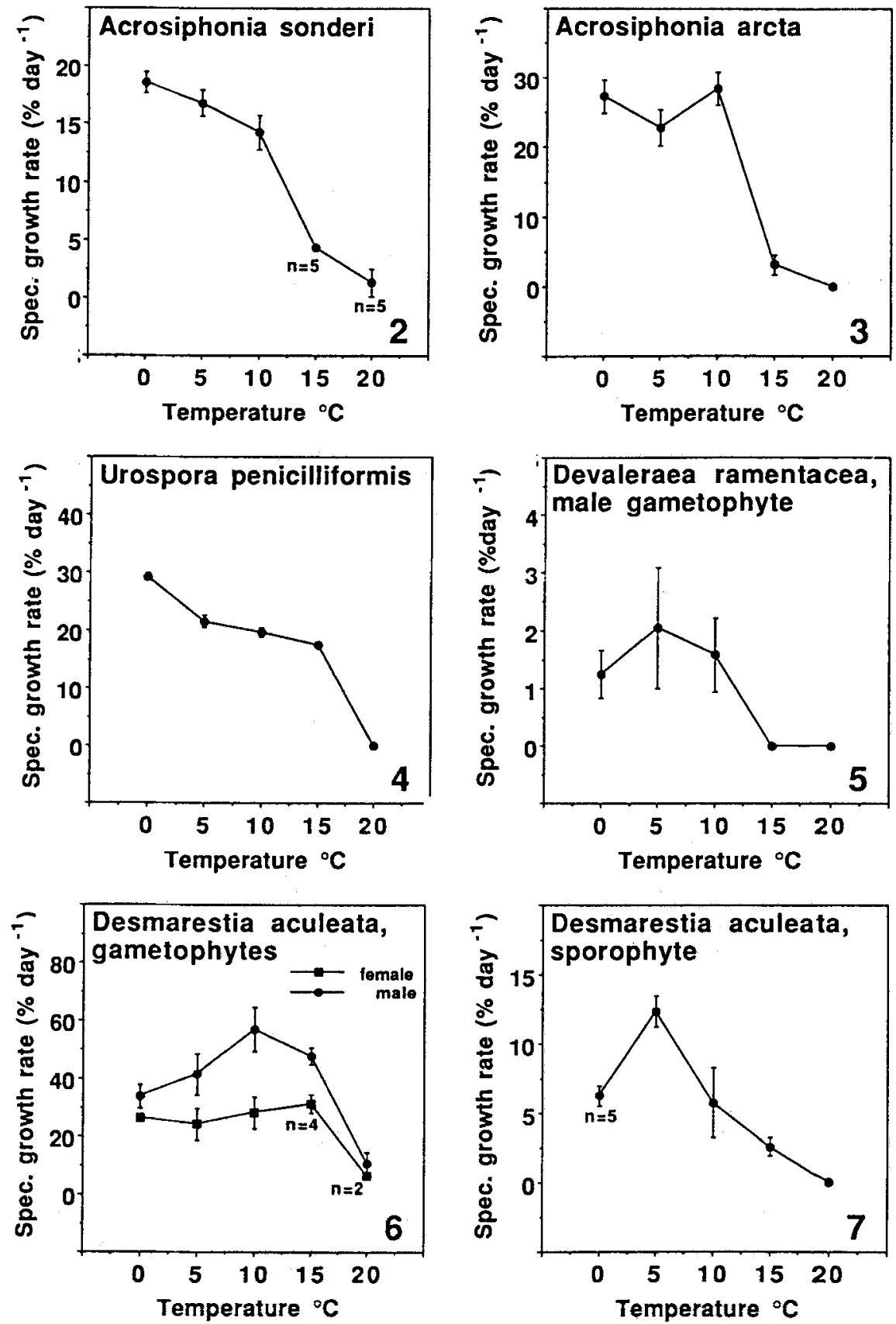

Figs 2-12. Temperature requirements for growth of macroalgae, isolated on Disko Island. Most experiments were performed as described in the legend of Figures 1a-e. Generally, the growth rates obtained in the measurement of the last interval were chosen to describe relationships between growth and temperature. N. B. The scales represent different values. Growth rates in Figure 10 were measured after 14 days. The experiments shown in Figures 5 and 6 were performed in Petri dishes at 

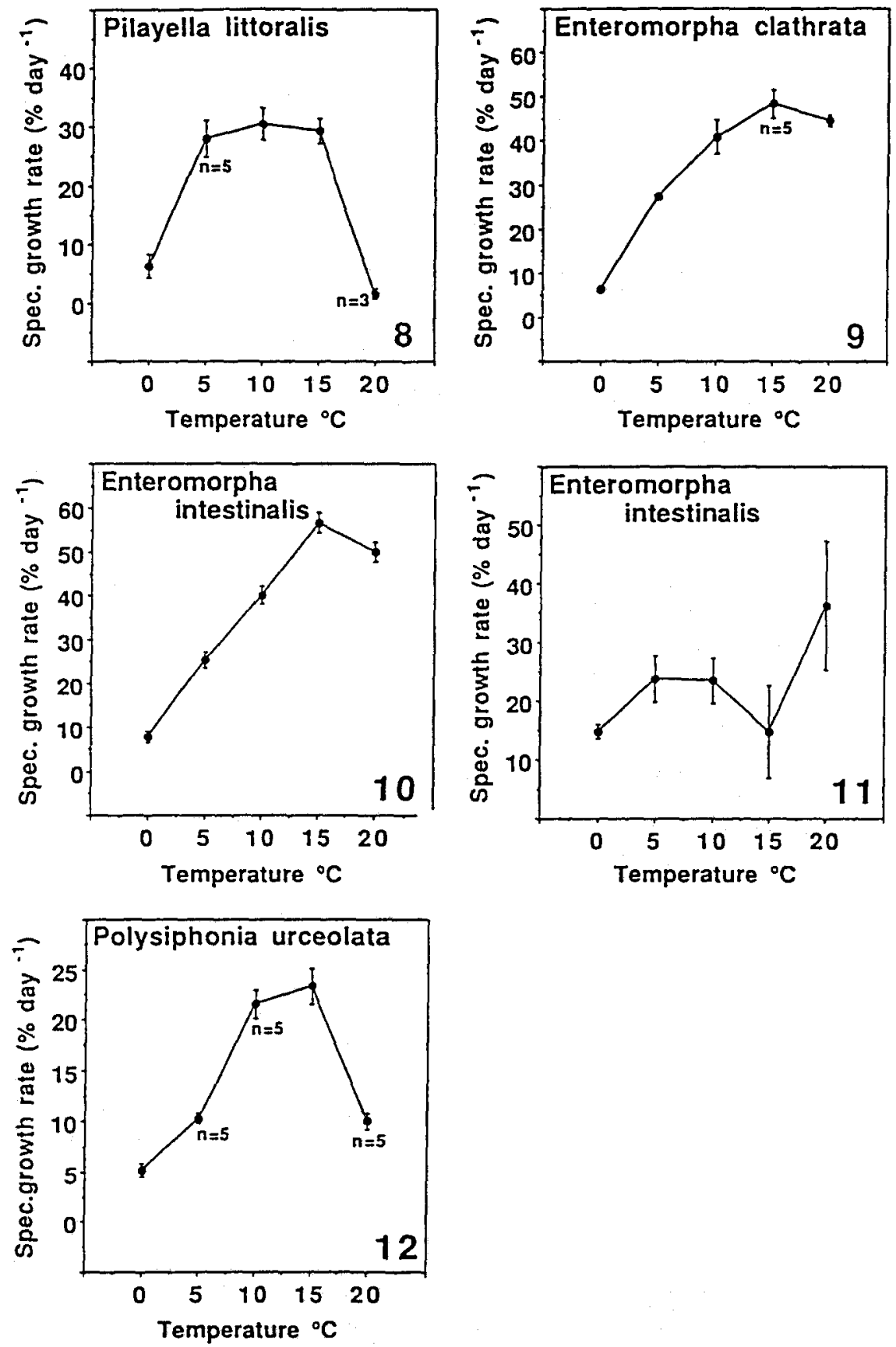

50 or $15 \mu \mathrm{mol} \mathrm{m}{ }^{-2} \mathrm{~s}^{-1}$, respectively, and the growth rates were determined in terms of area. Growth rates in Figure 5 were measured after a period of 42 days. Growth rates shown in Figure 6 were determined after 3 days, following a period of 5 days, where the algae had been maintained at the experimental temperature and light conditions $(n=3$, when not indicated) 
between 0 and $15^{\circ} \mathrm{C}$, whereas the male gametophyte grew optimally at $10^{\circ} \mathrm{C}$, and in both cases the USL was $22^{\circ} \mathrm{C}$ (Table 3). The sporophyte of $D$. aculeata only grew between 0 and $15^{\circ} \mathrm{C}$, with maximum rates at $5^{\circ} \mathrm{C}$ (Fig. 7). Two out of the three sporophytes survived $20^{\circ} \mathrm{C}$ (Table 3). Pilayella littoralis grew between 0 and $20^{\circ} \mathrm{C}$ with an optimum between 5 and $15^{\circ} \mathrm{C}$. At $20^{\circ} \mathrm{C}$ and also at $0^{\circ} \mathrm{C}$, only low growth rates were determined (Fig. 8). The USL was $21^{\circ} \mathrm{C}$ (Table 3). Chromastrum secundatum, Chromastrum virgatulum and the micro- and macrothalli of Chordaria flagelliformis survived up to $17^{\circ} \mathrm{C}, 21^{\circ} \mathrm{C}$ or $23^{\circ} \mathrm{C}$, respectively (Table 3 ).

Group 2, eurythermal species: Enteromorpha clathrata grew optimally between 10 and $20^{\circ} \mathrm{C}$ (Fig. 9), with $10 \%$ of the optimal growth rate at $0^{\circ} \mathrm{C}$. The USL was $31^{\circ} \mathrm{C}$ (Table 3). Enteromorpha intestinalis sporulated in some cases at 15 and $20^{\circ} \mathrm{C}$, resulting in a simultaneous decline of the growth rate. Figure 10 shows the growth rates from the first two weeks before sporulation, and Figure 11 from the week after sporulation. Ignoring the sporulation, growth was highest between 15 and $20^{\circ} \mathrm{C}$. This species tolerated $28^{\circ} \mathrm{C}$ (Table 3). Polysiphonia urceolata showed optimum growth between 10 and $15^{\circ} \mathrm{C}$ (Fig. 12), and two of the three test plants survived $26^{\circ} \mathrm{C}$ (Table 3). Ulva lactuca and Chaetomorpha tortuosa tolerated $26^{\circ} \mathrm{C}$, macrothalli of Bangia atropurpurea tolerated $23-24^{\circ} \mathrm{C}$, and the micro- and macrothalli of Eudesme virescens tolerated $30^{\circ} \mathrm{C}$ (Table 3). It is not known if gametophytes or (tetra-)sporophytes of E. clathrata, E. intestinalis, $P$. urceolata and $U$. lactuca were used, since these species have isomorphic life-history stages (Table 2).

\section{DISCUSSION}

\section{Methodological considerations}

In most previous macroalgal growth studies, specific growth rates $\left(\% \mathrm{~d}^{-1}\right)$ have been calculated as mean values over whole experimental periods mostly between 24 hours and months (e.g. Fortes \& Lüning, 1980; Bolton, 1983; Guiry et al., 1987; tom Dieck, 1989; Wiencke \& tom Dieck, 1989, 1990; Novaczek \& Breeman, 1990), although some investigations used experimental periods of up to seven months (Rueness \& Tanager, 1984; Yarish et al., 1986). In the current study, growth rates were determined weekly or fortnightly over 5 (or 6) weeks (Fig. 1a-e). The values obtained reflect the temperature acclimation of growth during this period. Rates from the last measurement were generally chosen to describe relationships between growth and temperature. If growth rates had been calculated over the whole time, the resulting temperature growth patterns would differ from those described. It is obvious that the growth rates of temperatureacclimated plants give a more precise indication of temperature-growth relationships than results obtained by a more simplified methodology. It must, however, be noted that this refined methodology can be used only with species, which grow consistently over long periods. In algae with internal growth rhythms (Lüning, 1991; tom Dieck, 1992a), this method is probably not applicable.

Changes in temperature have a fundamental influence on algal metabolism, and certain processes such as enzymatic reactions are strongly temperature dependent (Lobban et al., 1985). The balance between single metabolic steps or whole pathways may be altered by temperature changes (Berry \& Raison, 1981). After acclimation to a 


\begin{tabular}{|c|c|c|c|c|c|c|c|c|c|c|c|c|c|c|c|}
\hline 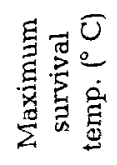 & & 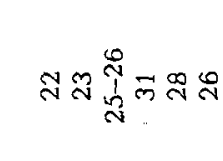 & & 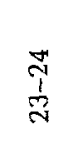 & 2 & 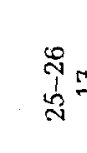 & $=\bar{\pi}$ & & $\widetilde{\pi}$ & $\tilde{n}$ & ส & ริ & N & $\begin{array}{l}0 \\
\text { 1 } \\
0 \\
0\end{array}$ & हैं \\
\hline & $\tilde{m}$ & $\vdots \vdots$ & & & & & & & & & & & & & $\vdots$ \\
\hline & $\vec{n}$ & $\underset{x}{x}$ & & & & & & & & & & & & & $\vdots$ \\
\hline & ஜ & $\underset{x}{x}$ & & & & & & & & & & & & & $x$ \\
\hline & สి & 希 & & & & & & & & & & & & & . \\
\hline & $\stackrel{\infty}{\sim}$ & $\vdots:$ & & & & & & & & & & & & & 落 \\
\hline & $\stackrel{N}{N}$ & : & & & & $\vdots$ & $\vdots \vdots$ & & $\vdots$ & $\vdots$ & $\vdots$ & & & $\vdots$ & : \\
\hline & $\stackrel{\circ}{\sim}$ & 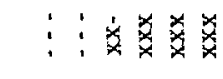 & & $\vdots$ & & 茨 & $\vdots \vdots$ & & $\vdots$ & $\vdots$ & $\vdots$ & & & $\vdots$ & $\underset{x}{x} \vdots$ \\
\hline $\mathscr{\Xi}$ & ต & 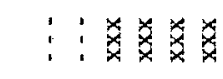 & & $\vdots$ & & $\ddot{x}$ & $\vdots \vdots$ & & $\vdots$ & $\vdots$ & $\vdots$ & & & $\vdots$ & : \\
\hline 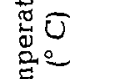 & 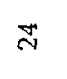 & $\begin{array}{l:l}1 & \vdots \\
1\end{array}$ & & : & & 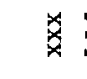 & $\vdots \vdots$ & & $\vdots$ & $\vdots$ & $\vdots$ & & $\vdots$ & $\vdots$ & $\ddot{x}$ \\
\hline 跑 & $\tilde{N}$ & 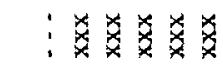 & & $\vdots: \underset{x}{x}$ & & & $\vdots \vdots$ & & $x$ & $x$ & $\vdots$ & & $\vdots$ & $\vdots$ & 苭 \\
\hline & $\approx$ & 㭉希 & & $\vdots: x$ & & & $\vdots \vdots$ & & $x$ & $\underset{x}{x}$ & $\stackrel{x}{*}$ & 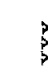 & 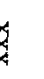 & $\vdots$ & $\underset{x}{x}$ \\
\hline & $\vec{N}$ & 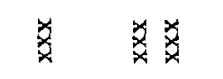 & $\ddot{x}$ & 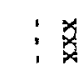 & 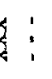 & & $\vdots \vdots \vdots \vdots \dot{x}$ & $\dot{x}$ & $\underset{x}{x}$ & 要 & 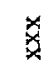 & 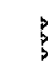 & 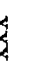 & $\vdots$ & 独 \\
\hline & 요 & & $x$ & : & 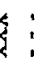 & & $\begin{array}{l}\vdots \\
\vdots\end{array} \vdots$ & & $\frac{1}{x}$ & $\not x$ & & & & $\dot{x}$ & \\
\hline & $\stackrel{2}{-1}$ & & 索 & $x$ & $\vec{x}$ & & $\begin{array}{l:l}\vdots \\
\vdots\end{array} \vdots$ & & : & : & & & & $\underset{x}{\breve{x}}$ & \\
\hline & $\stackrel{\infty}{\rightarrow}$ & & $\vec{x}$ & 希 & xx & & $\begin{array}{l}\vdots \\
\vdots\end{array} \vdots \begin{array}{c}x \\
x\end{array}$ & & 齐. & $\ddot{x}$ & & & & $x_{x}^{x}$ & \\
\hline & $=$ & & & x. & $\frac{x}{x}$ & & $\vdots$ & & . & 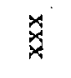 & & & & i & \\
\hline & $\stackrel{\circ}{\circ}$ & & & 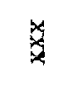 & $\underset{x}{x}$ & & $\vdots$ & & 㾔 & $\ddot{x}$ & & & & $\begin{array}{l}x \\
x \\
x \\
x\end{array}$ & \\
\hline 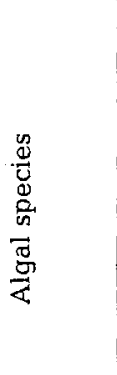 & & 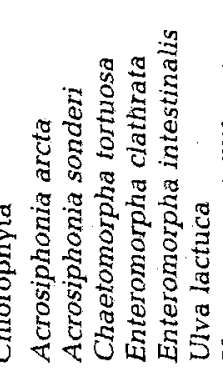 & 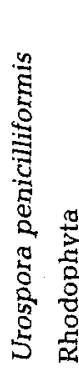 & 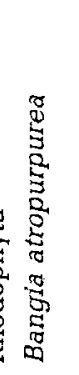 & 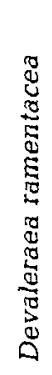 & 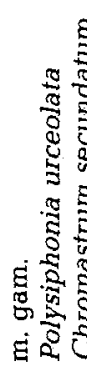 & 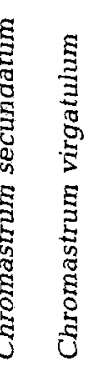 & & 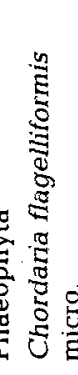 & 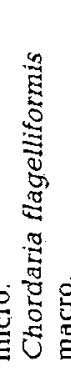 & 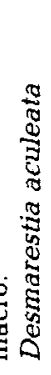 & 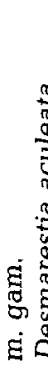 & 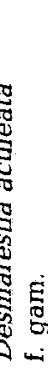 & 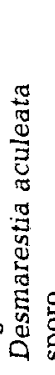 & 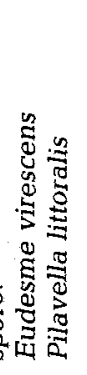 \\
\hline
\end{tabular}


respective temperature, metabolic processes are adjusted to an appointed rate, and a new balance is restored within an experimental time-span of mostly 5 weeks (Fig. 1).

There was frequently a large increase in growth during the first 2 to 3 weeks (Fig. 1a-d). It is conspicuous that, at $10^{\circ} \mathrm{C}$, a decrease was observed, although the algae had been cultivated at this temperature before experimentation. However during this time the cultures were quite dense. At the start of the growth measurements the density was reduced, and the increases in growth are possibly a reflection of acclimation to higher photon fluence rates, due to less self-shading. Studies on Scytosiphon lomentaria (Phaeophyta) and Bangia atropurpurea (Rhodophyta) have shown that acclimation to altered photon fluence rates requires a period of approx. 2 weeks (Orfanidis, 1992). This indicates the importance of keeping the amount of algal material relatively constant during a growth experiment, thereby avoiding shelf-shading effects.

\section{General temperature characteristics}

The isolated macroalgal species from Disko Island can be divided into two groups. The first group includes species with more stenothermal temperature requirements: Acrosiphonia arcta, Acrosiphonia sonderi, Urospora penicilliformis, Devaleraea ramentacea, Desmarestia aculeata, Pilayella littoralis, Chromastrum secundatum, Chromastrum virgatulum, Chordaria flagelliformis. These algae displayed a high degree of cold adaptation with respect to the growth ranges (mostly $\left.0-15^{\circ} \mathrm{C}\right)$ and optima $\left(0-10^{\circ} \mathrm{C}\right)$. The USL's $\left(17-23^{\circ} \mathrm{C}\right)$ were however - with the exception of $C$. secundatum and D. ramentacea - similar to those of algae from the cold-temperate regions (Bolton \& Lüning, 1982; Lüning, 1984; Lüning, 1985; Lüning \& Freshwater, 1988; tom Dieck, 1992b, 1993; Wiencke \& tom Dieck, 1990). The second group includes species with more eurythermal temperature requirements: Enteromorpha clathrata, Enteromorpha intestinalis, Polysiphonia urceolata, Ulva lactuca, Chaetomorpha tortuosa, Bangia atropurpurea, Eudesme virescens. The growth range was between 0 and $20^{\circ} \mathrm{C}$ with optimum growth between 10 and $15^{\circ} \mathrm{C}$ : typical for cold-temperate algae (Bolton \& Lüning, 1982; Lüning, 1984; Lüning, 1985; tom Dieck 1992b, 1993; Wiencke \& tom Dieck, 1990). These algae survived up to 24 or even $31^{\circ} \mathrm{C}$, similar to warm- and cold-temperate species (Yarish et al., 1987; Cambridge et al., 1987; Lüning, 1990).

These results show that macroalgae from the Arctic region are mostly less adapted to low temperatures than algae from the Antarctic region (Wiencke \& tom Dieck, 1989). This applies especially to the eurythermal group, both in regard to growth and temperaturetolerance level. The relatively high USL's of most species of the stenothermal group also indicates this trend. However, in some species from Disko Island unusually low temperature requirements were found.

The low USL of $C$. secundatum $\left(17^{\circ} \mathrm{C}\right)$ is the lowest so far to be determined in Arctic seaweeds, and nearly similar to those of endemic Antarctic macroalgae (Wiencke $\&$ tom Dieck, 1989). The temperature-growth ranges are expected to be relatively small with growth optima at low temperatures. The USL of the male gametophyte of the endemic Arctic red alga $D$. ramentacea was, at $19^{\circ} \mathrm{C}$ (Table 3), similarly low. The alga grew between 0 and $10^{\circ} \mathrm{C}$, with optimal values at $5^{\circ} \mathrm{C}$ (Fig. 5). Novaczek et al. (1990) found a different temperature requirement for optimum growth and survival between isolates from the Canadian Arctic and the European coast (Norway, Jan Mayen, Iceland). The 
isolates from both coasts grew between 0 and $10^{\circ} \mathrm{C}$, but the Canadian isolates grew optimally between 0 and $5^{\circ} \mathrm{C}$, and survived up to 20 and $23^{\circ} \mathrm{C}$ (experimental period: 2 weeks or 3 months, respectively). The European plants exhibited optimum growth between 5 and $10^{\circ} \mathrm{C}$, and USL's between 18 and $20^{\circ} \mathrm{C}$. The temperature requirements for growth and the USL of $D$. ramentacea are nearly similar to those of the endemic Antarctic species studies so far. For example, the endemic Antarctic alga Palmaria decipiens, which belongs to the same order Palmariales (Guiry, 1982), grows between 0 and $10^{\circ} \mathrm{C}$ (with an optimum at $5^{\circ} \mathrm{C}$ ); however, this species only tolerates temperatures of 16 to $17^{\circ} \mathrm{C}$ (Wiencke \& tom Dieck, 1989).

The growth optima at $0^{\circ} \mathrm{C}$ of $A$. sonderi and $U$. penicilliformis, and $A$. arcta between 0 and $10^{\circ} \mathrm{C}$ were unexpected (Figs. 2-4). Up to now, growth optima at $0^{\circ} \mathrm{C}$ in Arctic to cold-temperate species were found only in the above-discussed $D$. ramentacea (Novaczek et al., 1990). A. arcta as well as $U$. penicilliformis grew between 0 and $15^{\circ} \mathrm{C}$ and A. sonderi between 0 and $20^{\circ} \mathrm{C}$, with very low growth rates at $\geq 15^{\circ} \mathrm{C}$. Fortes \& Lüning (1980) described a growth range between 0 and $20^{\circ} \mathrm{C}$ with an optimum at $10^{\circ} \mathrm{C}$ for A. arcta from Helgoland. However, the investigation period was only 24 hours, and, hence, the results are not strictly comparable to results obtained in the present study (Fig. 3). Wiencke \& tom Dieck (1990) determined growth optima at $5^{\circ} \mathrm{C}$ for isolates of $A$. arcta and $U$. penicilliformis from King George Island (Antarctica). These rates were (in contrast to the current study) calculated over the whole investigation period of 28 days (+ 7 days for acclimation). Using the test methods of the present study, a growth optimum at $0^{\circ} \mathrm{C}$ can also be expected in the Antarctic isolates of these species. The USL's from the Arctic isolates of $A$. arcta and $U$. penicilliformis were 22 or $23^{\circ} \mathrm{C}$, respectively (Table 3 ), and from the Antarctic isolates 22 or $19^{\circ} \mathrm{C}$, respectively (Wiencke \& tom Dieck, 1990). The available data indicates an ecotypic variation in the temperature requirements for survival, and presumably also for growth, in the different Northern and Southern Hemisphere populations of these two species.

Desmarestia aculeata male and female gametophytes from Disko Island exhibited USL's of $22^{\circ} \mathrm{C}$, which are comparable to gametophytes from Helgoland and Western Canada (Peters \& Breeman, 1992), and a growth range between 0 and $20^{\circ} \mathrm{C}$ (optimum, male: $10^{\circ} \mathrm{C}$; female: 0 to $15^{\circ} \mathrm{C}$; Fig. 6). In this context, it must be noted that these growth values refer to an investigation time of only 3 days, preceded by 5 days exposure to experimental conditions. The sporophytes showed a lower temperature requirement than the gametophytes, similar to other brown algal species with heteromorphic life-histories (Breeman, 1988, 1990). The growth range of juvenile sporophytes was between 0 and $15^{\circ} \mathrm{C}$, with optimum rates at $5^{\circ} \mathrm{C}$ (Fig. 7). Young sporophytes of $D$. aculeata from Helgoland grew between 0 and $25^{\circ} \mathrm{C}$, with optimal values at $10^{\circ} \mathrm{C}$ (determined after $24 \mathrm{~h}$ exposure; Fortes \& Lüning, 1980). The isolate from Disko Island formed sporophytes at $5^{\circ} \mathrm{C}$, but not at $10^{\circ} \mathrm{C}$. This contrasts with isolates from Helgoland in which sporophyte formation was induced at the higher temperature (Lüning, 1981; Müller \& Lüthe, 1981), and shows an adaptation to environmental conditions of the Arctic region with respect to growth as well as reproduction. Juvenile sporophytes from Disko Island survived up to $20^{\circ} \mathrm{C}$ (Table 3). The USL's in young sporophytes from Helgoland was between 18 and $20^{\circ} \mathrm{C}$ (Lüning, 1984). Adult sporophytes from Helgoland and the Northeast Pacific survived up to 20 or $23^{\circ} \mathrm{C}$ and up to $23^{\circ} \mathrm{C}$, respectively (Lüning, 1984; Lüning \& Freshwater, 1988 ; incubation period: one 
week, photosynthetic evaluation). These results do not point to an ecotypic variation in this species with respect to the USL's.

The isolates of $P$. littoralis from Disko Island grew optimally between 5 and $15^{\circ} \mathrm{C}$ (Fig. 8), but with very low growth rates, and with a very reduced zoidangia formation at $20^{\circ} \mathrm{C}$; the USL was $21^{\circ} \mathrm{C}$ (Table 3). Isolates from Helgoland, Chile and Diego Ramirez Island (Drake Passage) grew optimally at $12^{\circ} \mathrm{C}$ and showed reduced formation of zoidangia at $20^{\circ} \mathrm{C}$ (Müller \& Stache, 1989). The isolate from Helgoland tolerated $25^{\circ} \mathrm{C}$ (Lüning, 1984; one-week test) and that from Diego Ramirez Island 22 to $23^{\circ} \mathrm{C}$ (Wiencke \& tom Dieck, 1990; two-week test). If the different methods are comparable, it is obvious that the growth optima, temperature requirements for reproduction and survival of the population from Disko Island are broadened towards lower temperatures, compared to cold-temperate isolates. This result is similar to that found in the comparable species Ectocarpus siliculosus (Bolton, 1983).

Enteromorpha clathrata from Disko Island grew between 0 and $20^{\circ} \mathrm{C}$ with an optimum between 10 and $20^{\circ} \mathrm{C}$ (Fig. 9). The upper temperature tolerance was $31^{\circ} \mathrm{C}$ (Table 3). An isolate from southernmost Chile showed the same temperature range, but grew optimally between 5 and $15^{\circ} \mathrm{C}$, with lower growth rates at $20^{\circ} \mathrm{C}$ than at $0^{\circ} \mathrm{C}$ (Wiencke \& tom Dieck, 1990). This isolate only tolerated 22 to $23^{\circ} \mathrm{C}$ (not shown in Table $3)$. If the taxonomic status of the two isolates is correct, these data may indicate the presence of temperature ecotypes in this species.

Bangia atropurpurea from Disko Island survived $24^{\circ} \mathrm{C}$ (Table 3), a result comparable to the USL of $25^{\circ} \mathrm{C}$ for an isolate from Helgoland (Lüning, 1984). The USL of this species from Lake Ontario was between 30 and $35^{\circ} \mathrm{C}$ (Graham \& Graham, 1987; two to four weeks; photosynthetic evaluation) indicating ecotypic variation. In contrast, isolates of Polysiphonia urceolata, Chaetomorpha tortuosa and Ulva lactuca from Helgoland had an USL at $25^{\circ} \mathrm{C}, 26^{\circ} \mathrm{C}$ or $28^{\circ} \mathrm{C}$, respectively, (Lüning, 1984); this was similar to the temperature tolerance of these species from Disko Island (Table 3).

Many of the investigated species from Disko Island exhibited an adaptation to low temperatures with respect to growth and reproduction, but only two species, Chromastrum secundatum, Devaleraea ramentacea, showed an adaptation to low temperatures with respect to the USL. This is another indication for the assumption that the temperature tolerance is - in contrast to the temperature requirements for growth and reproduction - a very conservative trait (cf. Breeman, 1988; Novaczek et al., 1989; Lüning, 1990), which probably only changes over long evolutionary periods in macroalgae and other organisms. In molluscs, for example, cold water adaptation is performed in two steps (Scarlato, 1977): firstly, an initial broadening of survival and reproduction ranges towards lower temperatures and secondly, a loss of ability to survive higher temperatures. Similar processes of cold-adaptation may occur in macroalgae (Lüning \& tom Dieck, 1989). In this respect, the relatively short cold-water history of only $2 \mathrm{Ma}$ in the Arctic region may not be sufficient to alter the USL's more markedly and in a larger number of species. A higher degree of adaptation to low temperatures has so far only been shown in species from the Antarctic region, where water temperatures have been low for the much longer period of $25 \mathrm{Ma}$ (Grant-Meckie, 1979). This applies not only to endemic Antarctic species (Wiencke \& tom Dieck, 1989), but also to Acrosiphonia arcta, Urospora penicilliformis and other polar-cold temperate species from Antarctica (Wiencke \& tom Dieck, 1990). 


\section{Phytogeographic analysis}

The temperature requirements for growth, reproduction and survival are primarily responsible for determining distribution boundaries of macroalgae: Northern distribution limits of Arctic cold-temperate species are determined by summer temperatures which are too low for growth and/or reproduction, whereas southern boundaries are set by either lethally high summer temperatures, or extreme winter temperatures (van den Hoek, 1982a, b; Breeman, 1988, 1990). In this connection, it is important to take into consideration that the temperatures of near-shore coastal waters may in fact be different from temperatures in the open ocean (van den Hoek, 1982b; van den Hoek \& Breeman, 1989). The geographical distributions (in relation to described temperature demands) of the species investigated in this study are discussed below.

Acrosiphonia sonderi is found on both coasts of the N Atlantic, but is absent in the Canadian Arctic. It has only been recorded from one site in the Pacific - an indication of incomplete collecting (Fig. 13). The southern distribution boundary in the NW Atlantic extends along the $20^{\circ} \mathrm{C}$ August isotherm $\left(20^{\circ} \mathrm{S}\right)$. If the temperature requirement of the Disko Island isolate is extrapolated, this boundary is probably set by the upper growth $\left(20^{\circ} \mathrm{C}\right)$ and/or survival $\left(23^{\circ} \mathrm{C}\right)$ limit. The southern distribution boundary in the NE Atlantic corresponds with the $8^{\circ} \mathrm{C}$ February isotherm $\left(8^{\circ} \mathrm{W}\right)$. It is presumed that the distribution on this coast is limited by the formation of asexual propagules (Table 2), which were not observed at $\leq 10^{\circ} \mathrm{C}$.

\section{Acrosiphonia sonderi}

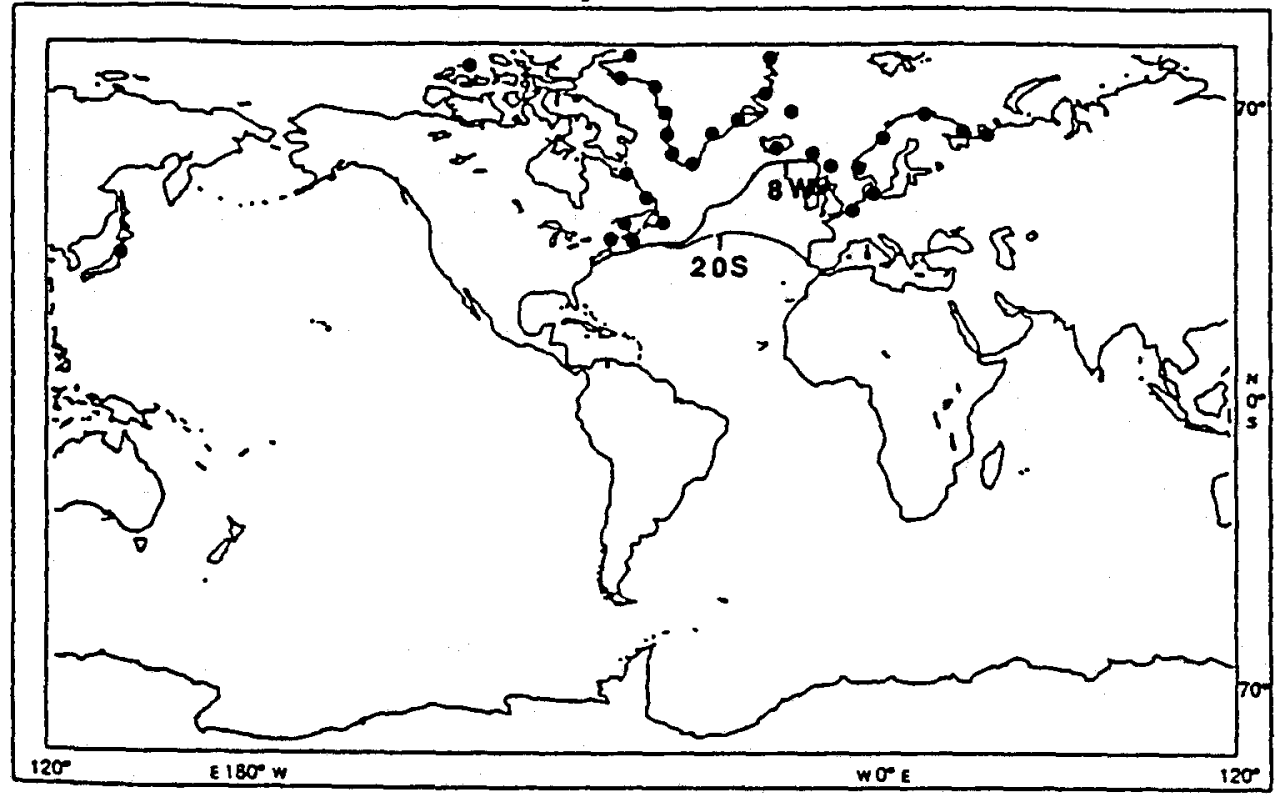

Fig. 13. Distribution of Acrosiphonia sonderi. Thick line (W): limiting winter isotherm. Thin line (S): limiting summer isotherm. (Distribution according to Pedersen, 1976; South, 1984; South \& Tittley, 1986; van den Hoek [pers. comm.].) 


\section{Devaleraea ramentacea}

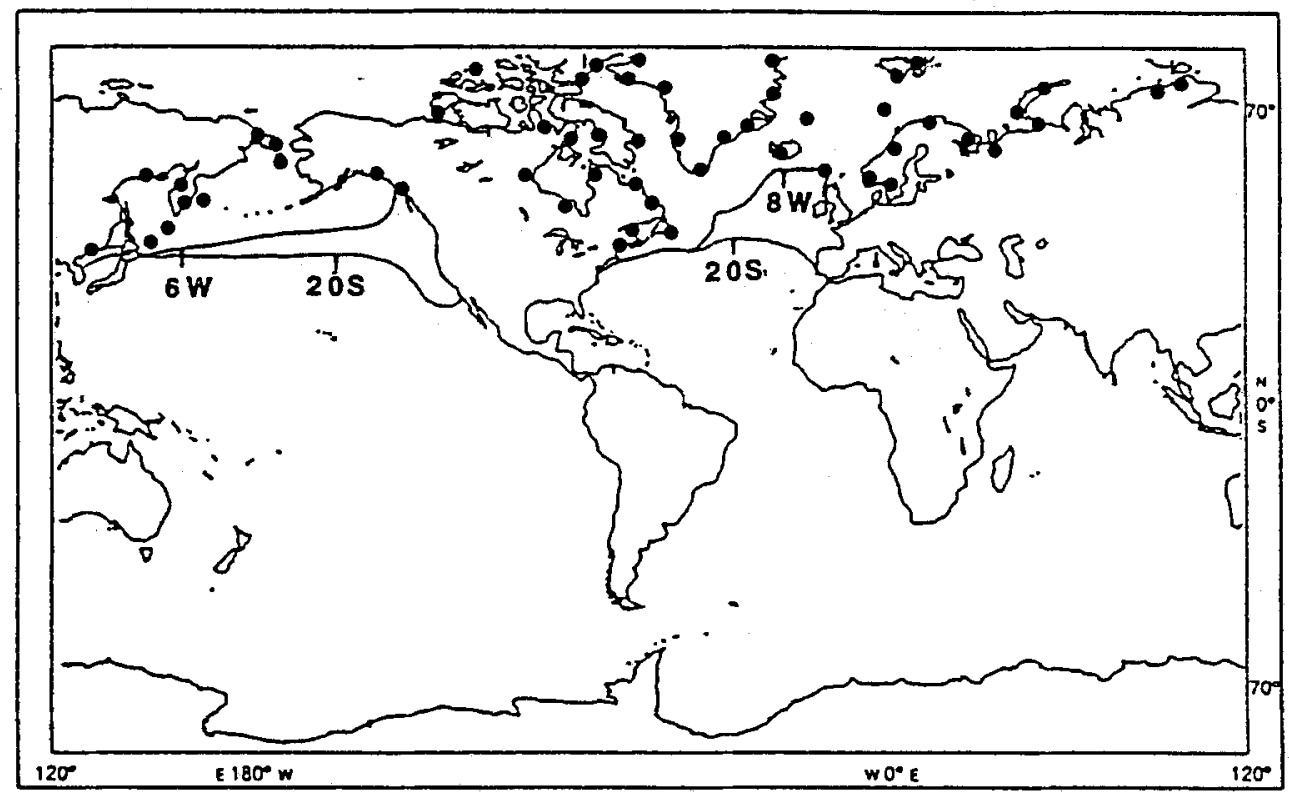

Fig. 14. Distribution of Devaleraea ramentacea. Thick line (W): limiting winter isotherm. Thin line (S): limiting summer isotherm. (Distribution according to Kjellman, 1883; Pedersen, 1976; Scagel et al., 1989; South, 1984; South \& Tittley, 1986.)

The southern distribution of the endemic Arctic alga Devaleraea ramentacea is limited in the $\mathrm{N}$ Atlantic through the $20^{\circ} \mathrm{S}$ and $8^{\circ} \mathrm{W}$ isotherms (Fig. 14). The southern boundary in the NW Atlantic seems to be a lethal boundary. In support of this, $D$. ramentacea from the Canadian Arctic had USL's between 20 and $23^{\circ} \mathrm{C}$ (Novaczek et al., 1990), but the survival temperature of the Disko Island isolate $\left(19^{\circ} \mathrm{C} ;\right.$ Table 3$)$ does not explain this. Novaczek et al. (1990) showed different temperature requirements for optimum growth and survival between isolates from the Canadian Arctic and the European coast. The temperature requirement of the isolate from Greenland, studied here, is similar to that of the European isolates (see Section B). It can therefore be hypothesised that this species recolonised Greenland from the European coast after the last Pleistocene glaciation. The distribution boundary in the NE Atlantic correlates with the $8^{\circ} \mathrm{W}$ isotherm. This area is probably limited through the temperature requirement for growth and reproduction, since this species only grew between 0 and $10^{\circ} \mathrm{C}$, and fertilisation has been observed between -2 and $8^{\circ} \mathrm{C}$ with optima at $5^{\circ} \mathrm{C}$ (A. M. Breeman, pers. comm.). The distribution boundary in the NW Pacific extends along the $20^{\circ} \mathrm{S}$ isotherm, suggesting a lethal boundary similar to that in the NW Atlantic. On the NE Pacific coast, the boundary $\left(6^{\circ} \mathrm{W}\right)$ is lower than in the NE Atlantic. This implies differences in the temperature requirement for growth and/or reproduction in the Pacific and Atlantic populations.

The southern distribution boundary of Desmarestia aculeata in the $\mathrm{N}$ Atlantic extends along the $22^{\circ} \mathrm{S}$ and $16^{\circ} \mathrm{W}$ isotherms (Fig. 15). This species grows in the sublit- 


\section{Desmarestia aculeata}

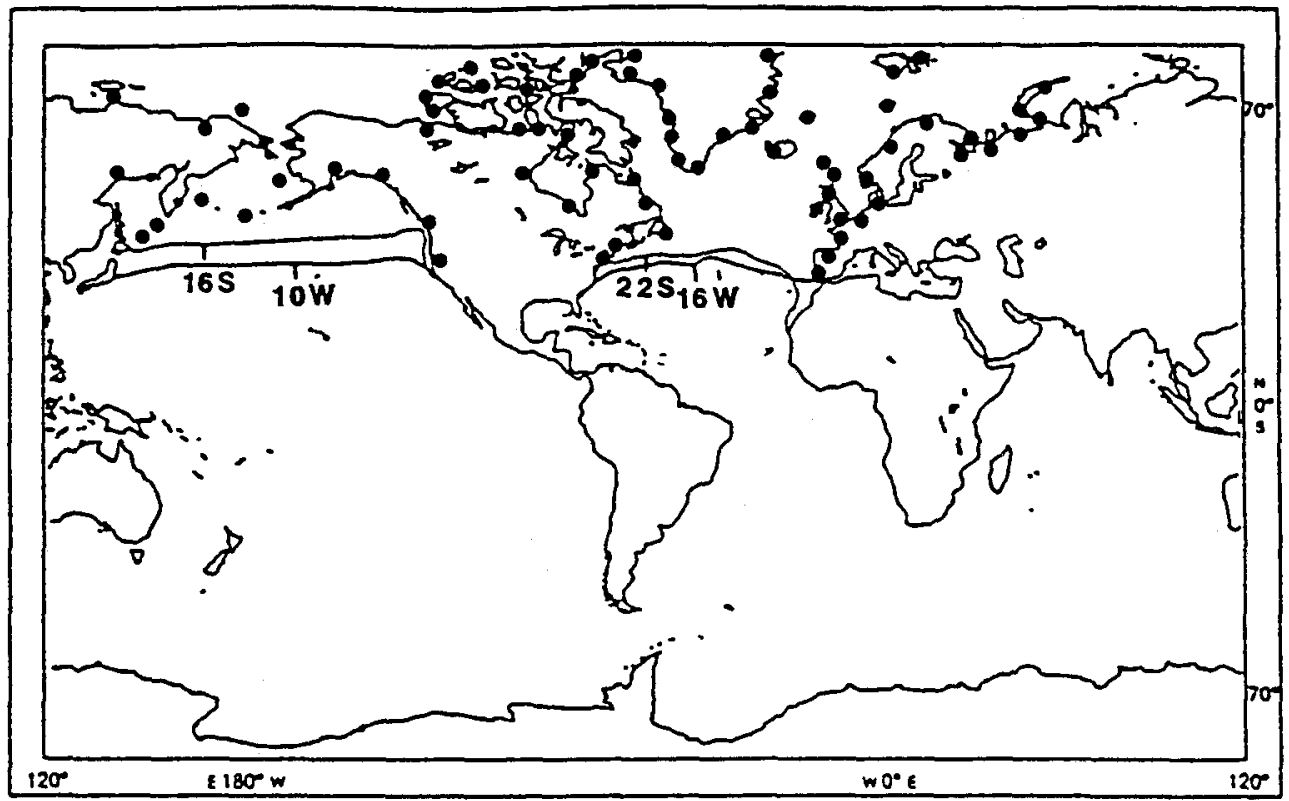

Fig. 15. Distribution of Desmarestia aculeata. Thick line (W): limiting winter isotherm. Thin line (S): limiting summer isotherm. (Distribution according to Kjellman, 1883; Pedersen, 1976; Scagel, 1957; Scagel et al., 1989; South, 1984; South \& Tittley, 1986.)

toral, where temperatures are lower than at the surface. The distribution on the NW Atlantic coast, described by the $22^{\circ} \mathrm{S}$ isotherm, can be explained by the USL of gametophytes and/or sporophytes $\left(22\right.$ or $20-23^{\circ} \mathrm{C}$, respectively, Table 3 ; Section $\left.B\right)$. The southern distribution on the NE Atlantic coast $\left(16^{\circ} \mathrm{W}\right)$ is evidently limited by the temperature requirement for reproduction, since the gametophyte USL's would permit a more southerly distribution. On the other hand, the temperature requirement for reproduction of the Disko Island isolate $\left(\leq 5^{\circ} \mathrm{C}\right)$ and the Helgoland isolate $\left(\leq 10^{\circ} \mathrm{C}\right)$ is not sufficient to explain this boundary. It is foreseeable that further ecotypic differentiation has occured. The distribution on the NE Pacific coast is limited by the $16^{\circ} \mathrm{S}$ and $10^{\circ} \mathrm{W}$ isotherms (Fig. 15). In all probability, the $16^{\circ} \mathrm{S}$ isotherm does not represent the southern boundary, because the USL of sporophytes from this coast was $23^{\circ} \mathrm{C}$ (Lüning \& Freshwater, 1988; Section B). Therefore it is to be expected that the southern boundary is set by the $10^{\circ} \mathrm{W}$ isotherm. It appears that the information about the distribution in the NW Pacific is incomplete $\left(16^{\circ} \mathrm{S}\right)$, since it would be expected that this species could occur at least down to the $10^{\circ} \mathrm{W}$ isotherm (Fig. 15). Based on the USL of the gametophytes, it is probable that $D$. aculeata could be found even further south.

The distributions of Chromastrum secundatum and Chromastrum virgatulum are unknown. The southern distribution in the NW Atlantic could be limited through the USL's (21 or $17^{\circ} \mathrm{C}$, respectively). During cultivation at $10^{\circ} \mathrm{C}$, growth and monospore formation (Table 2) was observed, therefore in the NE Atlantic this species could extend at least down to the $10^{\circ} \mathrm{W}$ isotherm. 
The southern distribution of Polysiphonia urceolata on the NW Atlantic coast is limited by the $22^{\circ} \mathrm{S}$ isotherm. The USL $\left(26^{\circ} \mathrm{C} ;\right.$ Table 3$)$ of the Disko Island isolate points to a lethal boundary. The southern boundary in the NE Atlantic $\left(14^{\circ} \mathrm{W}\right)$ is probably limited by the temperature requirement for reproduction. Because of the growth range $(0$ to $\left.20^{\circ} \mathrm{C}\right)$ and the USL $\left(26^{\circ} \mathrm{C}\right)$, this species could potentially occur on the NW African coast (Fig. 16). The southern distribution in the NW Pacific can be characterised by the $26^{\circ} \mathrm{S}$ and $16^{\circ} \mathrm{W}$ isotherm. It could be a combination between a lethal and reproduction boundary. The southern distribution in the NE Pacific reaches North Washington $\left(16^{\circ} \mathrm{S}\right.$, $8^{\circ} \mathrm{W}$ ). The distribution potential of this species would appear to be underexploited on this uninterrupted rocky coast.

\section{Polysiphonia urceolata}

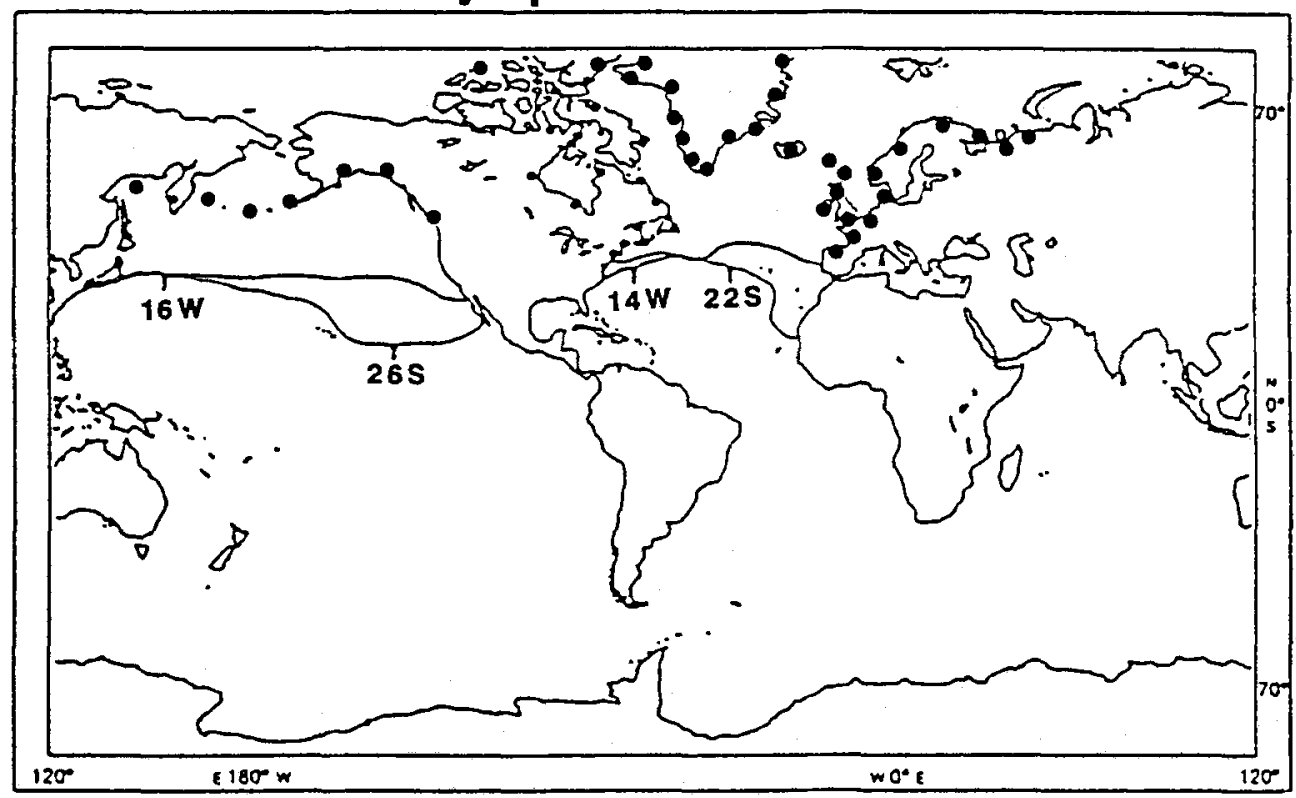

Fig. 16. Distribution of Polysiphonia urceolata. Thick line (W): limiting winter isotherm. Thin line (S): limiting summer isotherm. (Distribution according to Kjellman, 1883; Lindauer et al., 1961; Papenfuss, 1964; Pedersen, 1976; Scagel, 1957; Scagel et al., 1989; South, 1984; South \& Tittley, 1986.)

The southern distribution of Acrosiphonia arcta in the NW Atlantic correlates with the $22^{\circ} \mathrm{S}$ isotherm (Fig. 17). The USL of the Disko Island isolate $\left(22^{\circ} \mathrm{C}\right.$; Table 3$)$ explains this boundary. On the NE Atlantic coast this species is found up to the $14^{\circ} \mathrm{W}$ isotherm. This boundary can be set by growth, since this isolate had negative growth rates at $20^{\circ} \mathrm{C}$ and very low rates at $15^{\circ} \mathrm{C}$ (Fig. 3). Moreover, low temperature requirements for spore formation can explain this boundary (cf. van den Hoek, 1982b). The southern distribution boundary in the $\mathrm{N}$ Pacific extends along the $26^{\circ} \mathrm{S}$ isotherm in the West and along the $12^{\circ} \mathrm{W}$ isotherm in the East (Fig. 17). Based on the one available record, the $26^{\circ} \mathrm{S}$ isotherm is a southern lethal boundary. Possibly, this species occurs in this region during limited periods, surviving the warm summers as crusts. The distribution on the NE Pacific coast 
Acrosiphonia arcta

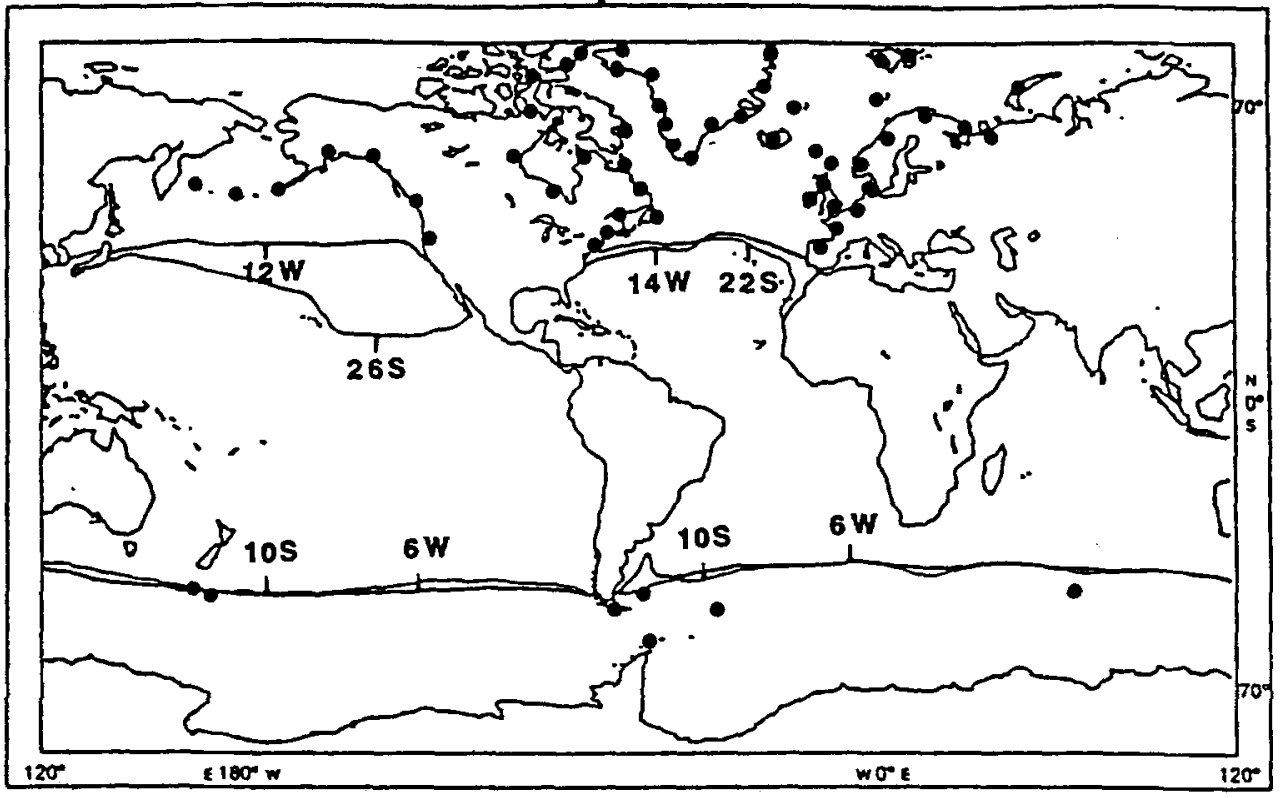

Fig. 17. Distribution of Acrosiphonia arcta. Thick line (W) limiting winter isotherm. Thin line (S): limiting summer isotherm. (Distribution according to Gabrielson et al., 1989; Kjellman, 1883; Levring, 1960; Papenfuss, 1964; Pedersen, 1976; Scagel, 1957; Scagel et al., 1989; South, 1984; South \& Tittley, 1986; Taylor, 1939; Tseng, 1983.)

reaches the $12^{\circ} \mathrm{W}$ isotherm indicating a growth and/or reproduction boundary. The northern distribution in both oceans of the Southern Hemisphere is limited by the $10^{\circ} \mathrm{S}$ and $6^{\circ} \mathrm{W}$ isotherms (Fig. 17). The temperature requirement for growth (range 0 to $15^{\circ} \mathrm{C}$ ), and the USL $\left(22^{\circ} \mathrm{C}\right)$ of an isolate from Antarctica (Wiencke \& tom Dieck, 1990) infer that $A$. arcta should be found even further north.

The southern distribution in the Northern Hemisphere of Urospora penicilliformis extends along the $26^{\circ} \mathrm{S}$ and $16^{\circ} \mathrm{W}$ isotherms (Fig. 18). It is expected that the distribution on the west coasts $\left(26^{\circ} \mathrm{S}\right)$ of the oceans is limited by a lethal boundary. Nevertheless, the USL of the Disko Island isolate $\left(23^{\circ} \mathrm{C}\right)$ is not sufficient to explain this boundary. This may indicate a seasonal occurrence in areas with high summer temperatures, or ecotypic variation between populations. The distribution on the east coasts of the oceans, which is limited by the $14^{\circ} \mathrm{W}$ isotherm, is a growth and/or reproduction boundary. The Disko Island isolate grew between 0 and $15^{\circ} \mathrm{C}$ (Fig. 4), and fertilisation was recorded in isolates from Helgoland at $15^{\circ} \mathrm{C}$ (Kornmann, 1966a). In the Southern Hemisphere the northern distribution is limited in the Pacific along the $16^{\circ} \mathrm{S}$ and $12^{\circ} \mathrm{W}$ isotherms. The northern distribution in the Atlantic is characterised by the $12^{\circ} \mathrm{S}$ and $8^{\circ} \mathrm{W}$ isotherm (Fig. 18). $U$. penicilliformis from Antarctica grows between 0 and $15^{\circ} \mathrm{C}$, and survives up to $19^{\circ} \mathrm{C}$ (Wiencke \& tom Dieck, 1990; Section B), certainly indicating incomplete collections. 


\section{Urospora penicilliformis}

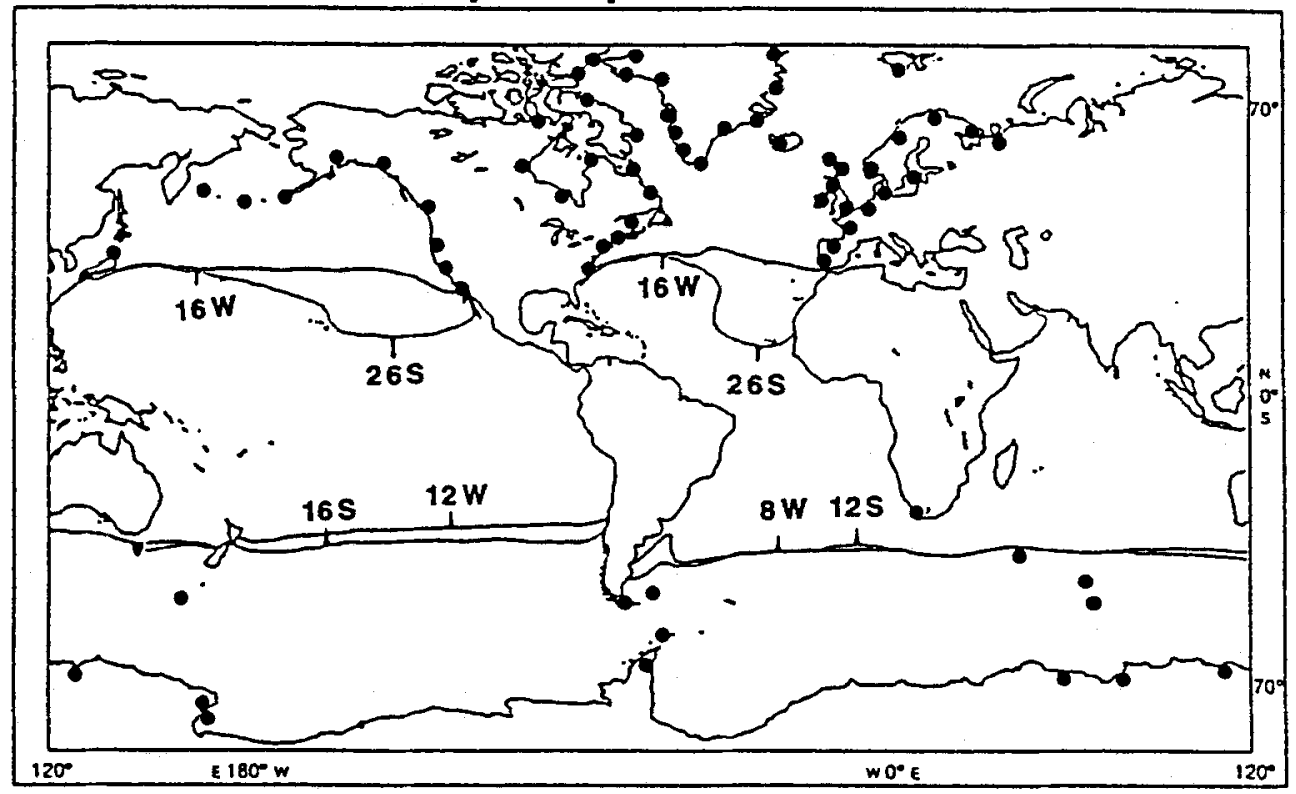

Fig. 18. Distribution of Urospora penicilliformis. Thick line (W): limiting winter isotherm. Thin line (S): limiting summer isotherm. (Distribution according to Chapman, 1956; Gabrielson et al., 1989; Kjellman, 1883; Lamb \& Zimmerman, 1977; Papenfuss, 1964; Pedersen, 1976; Ricker, 1987; Scagel, 1957; Scagel et al., 1989; Seagrief, 1984; South, 1984; South \& Tittley, 1986; Tseng, 1983; Wagner \& Zaneveld, 1988; Womersley, 1984.)

The southern distribution boundary of Pilayella littoralis in the Northern Hemisphere is correlated with the $26^{\circ} \mathrm{S}$ and $16^{\circ} \mathrm{W}$ isotherms (Fig. 19), which extend to almost identical positions in the $\mathrm{W}$ Atlantic and $\mathrm{W}$ Pacific. Its southern distribution may be limited by both the temperature requirements for growth/reproduction, and survival. However, the available data on USL's of the Disko Island isolate $\left(21^{\circ} \mathrm{C}_{i}\right.$ Table 3$)$ and of an isolate from Helgoland $\left(25^{\circ} \mathrm{C}\right.$; Lüning, 1984 ; Section B) cannot explain a lethal boundary. The distribution on both east coasts extends along the $16^{\circ} \mathrm{W}$ isotherm. The very low growth rates and the strongly reduced formation of zoidangia at $20^{\circ} \mathrm{C}$ of the Disko Island isolate indicates a growth and/or reproduction boundary. The northern distribution in the $\mathrm{S}$ Pacific is limited by the $18^{\circ} \mathrm{S}$ and $14^{\circ} \mathrm{W}$ isotherms, and in the Atlantic by the $10^{\circ} \mathrm{S}$ and $6^{\circ} \mathrm{W}$ isotherms (Fig. 19). Isolates from South Chile grew optimally at $12^{\circ} \mathrm{C}$ (Müller \& Stache, 1989), and survived up to 22 or $23^{\circ} \mathrm{C}$ (Wiencke \& tom Dieck, 1990), indicating that $P$. littoralis should be found even further north.

In the $\mathrm{N}$ Atlantic, the southern distribution of Chordaria flagelliformis is limited by the $18^{\circ} \mathrm{S}$ and $10^{\circ} \mathrm{W}$ isotherms (Fig. 20). The distribution boundary on the NW Atlantic coast is characterised by the $18^{\circ} \mathrm{S}$ isotherm, inferring a lethal boundary, since micro- and macrothalli of the Disko Island isolate survived up to $23^{\circ} \mathrm{C}$ (Table 3 ). The southern distribution on the NE Atlantic coast is limited by both isotherms (Fig. 20). In microthalli, 
Pilayella littoralis

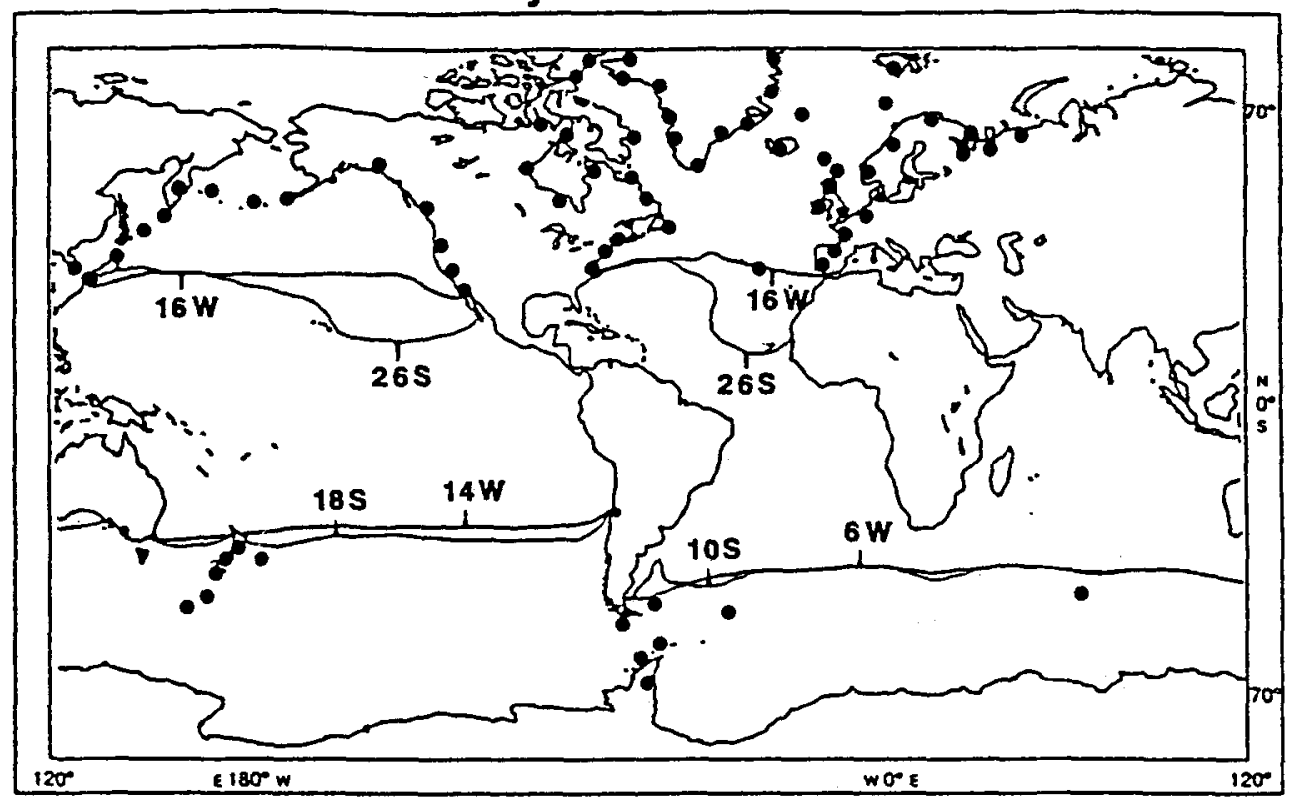

Fig. 19. Distribution of Pilayella littoralis. Thick line (W): limiting winter isotherm. Thin line (S): limiting summer isotherm. (Distribution according to Asensi, 1966; Etcheverry, 1983; Hay et al., 1985; Kjellman, 1983; Levring, 1945, 1960; Lindauer et al,, 1961; Pedersen, 1976; Ricker, 1987; Santelices \& Abbott, 1978; Scagel, 1957; Scagel et al., 1989; Skottsberg, 1907; South, 1984; South \& Tittley, 1986; Taylor, 1939.)

Chordaria flagelliformis

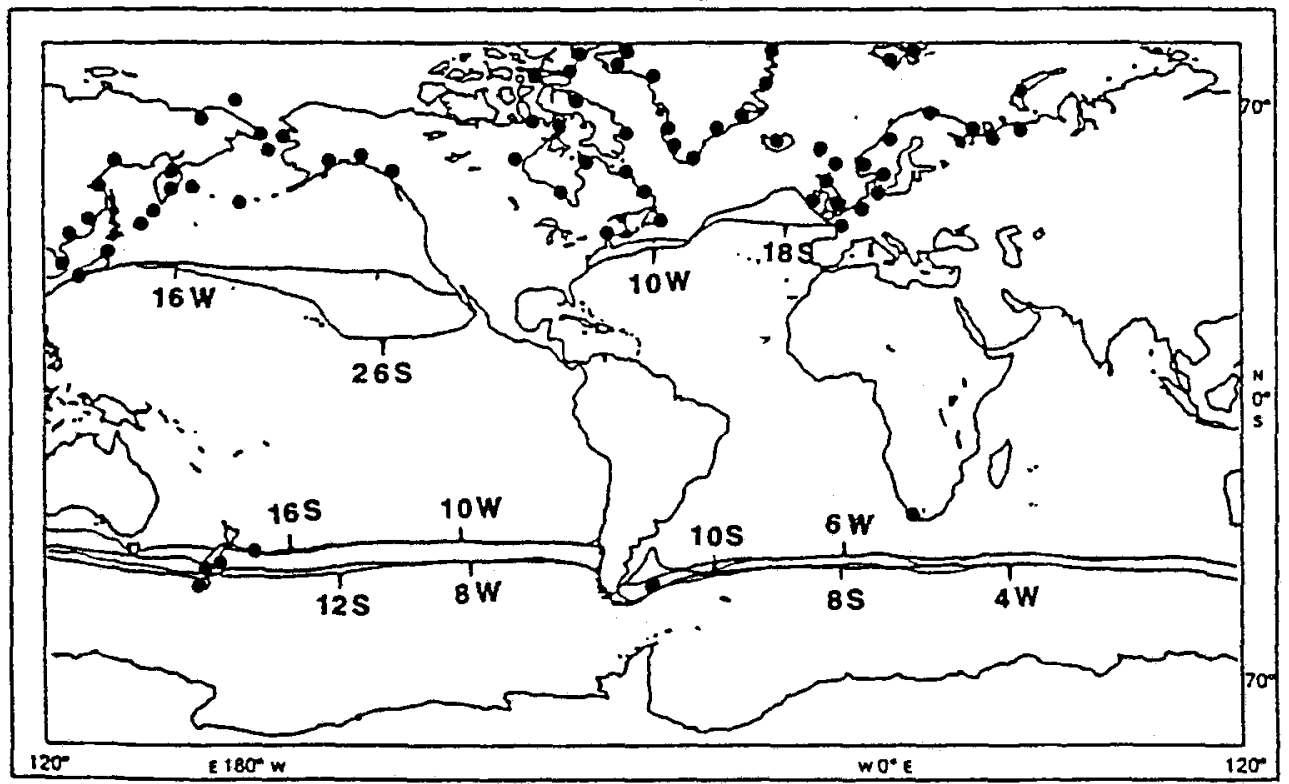

Fig. 20. Distribution of Chordaria flagelliformis. Thick line (W): limiting winter isotherm. Thin line (S): limiting summer isotherm. (Distribution according to Gabrielson et al., 1989; Kjellman, 1883; Lindauer et al., 1961; Papenfuss, 1964; Pedersen, 1976; Scagel et al., 1989; Seagrief, 1984; Skottsberg, 1921; South, 1984; South \& Tittley, 1986.) 
growth was observed at 5,10 and $15^{\circ} \mathrm{C}$ (data not shown). Therefore the distribution cannot be limited by the temperature-growth characteristics of this species. Rather, the distribution is limited by the temperature requirement for formation of macrothalli as the induction of macrothalli was observed at 5 and $10^{\circ} \mathrm{C}$ only. This is supported by the observations of Kornmann (1962), who only found macrothalli between spring and autumn.

The southern distribution of Chaetomorpha tortuosa in the $\mathrm{N}$ Atlantic is described in Figure 21 . As the USL of $26^{\circ} \mathrm{C}$ (Table 3 ) is the only experimental information available on the temperature demands of this species, it is impossible to explain the nature of these boundaries.

\section{Chaetomorpha tortuosa}

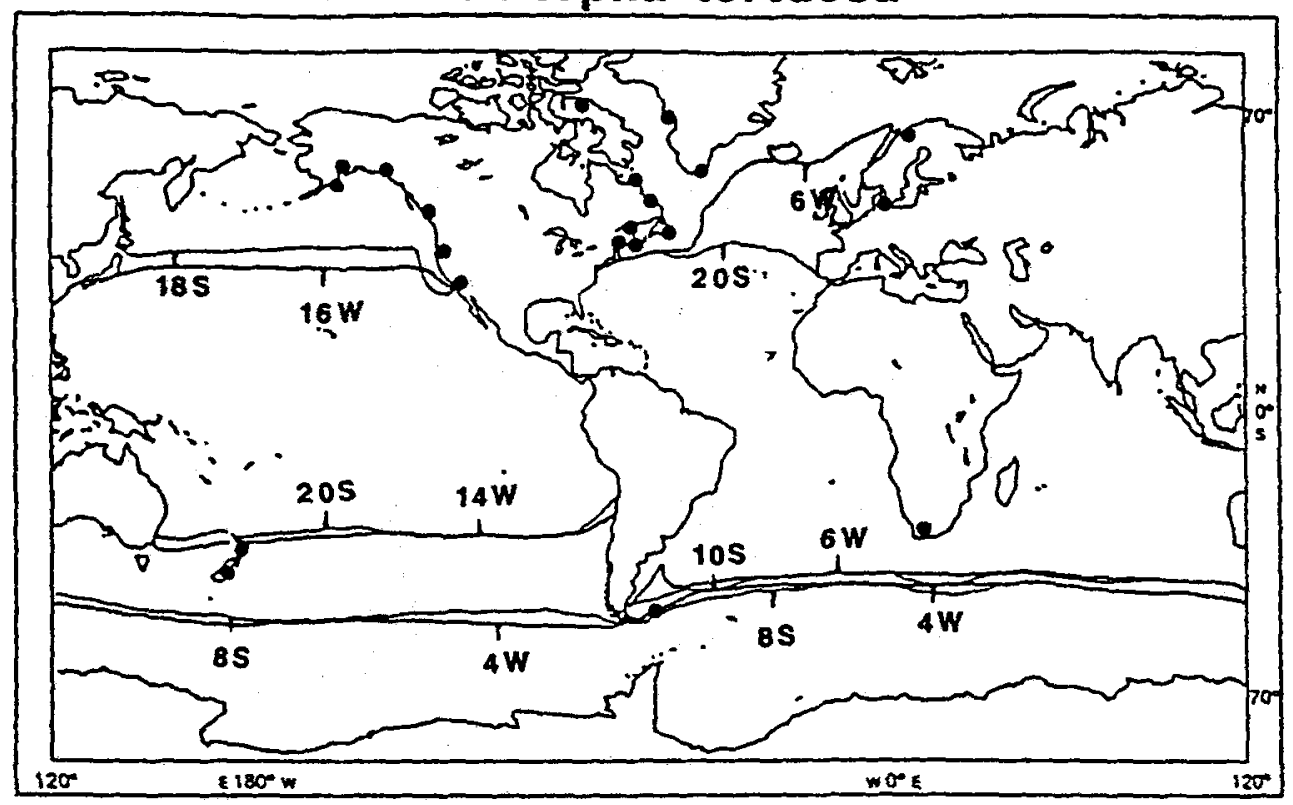

Fig. 21. Distribution of Chaetomorpha tortuosa. Thick line (W): limiting winter isotherm. Thin line (S): limiting summer isotherm. (Distribution according to Chapman, 1956; Kjellman, 1883; Papenfuss, 1964; Pedersen, 1976; Scagel, 1957; Scagel et al:, 1989; South, 1984.)

The southern distribution of Ulva lactuca on the NW coasts in the N Atlantic and N Pacific is limited by the $26^{\circ} \mathrm{S}$ isotherms (Fig. 22), certainly representing a lethal boundary, as the USL of the Disko Island isolate is $26^{\circ} \mathrm{C}$ (Table 3). The occurrence in W Florida (Dawes, 1974), where the temperature of surface coastal waterscan reaches $30^{\circ} \mathrm{C}$, points to a seasonal appearance at this site or to a misidentification (Schneider \& Searles, 1991). The distribution on the east coasts is characterised by the $16^{\circ} \mathrm{W}$ isotherm (Fig. 22). The Disko Island isolate grew well, with sporulation taking place during cultivation at 10 and $15^{\circ} \mathrm{C}$. This may indicate that the distribution is limited by the temperature requirement 


\section{Ulva lactuca}

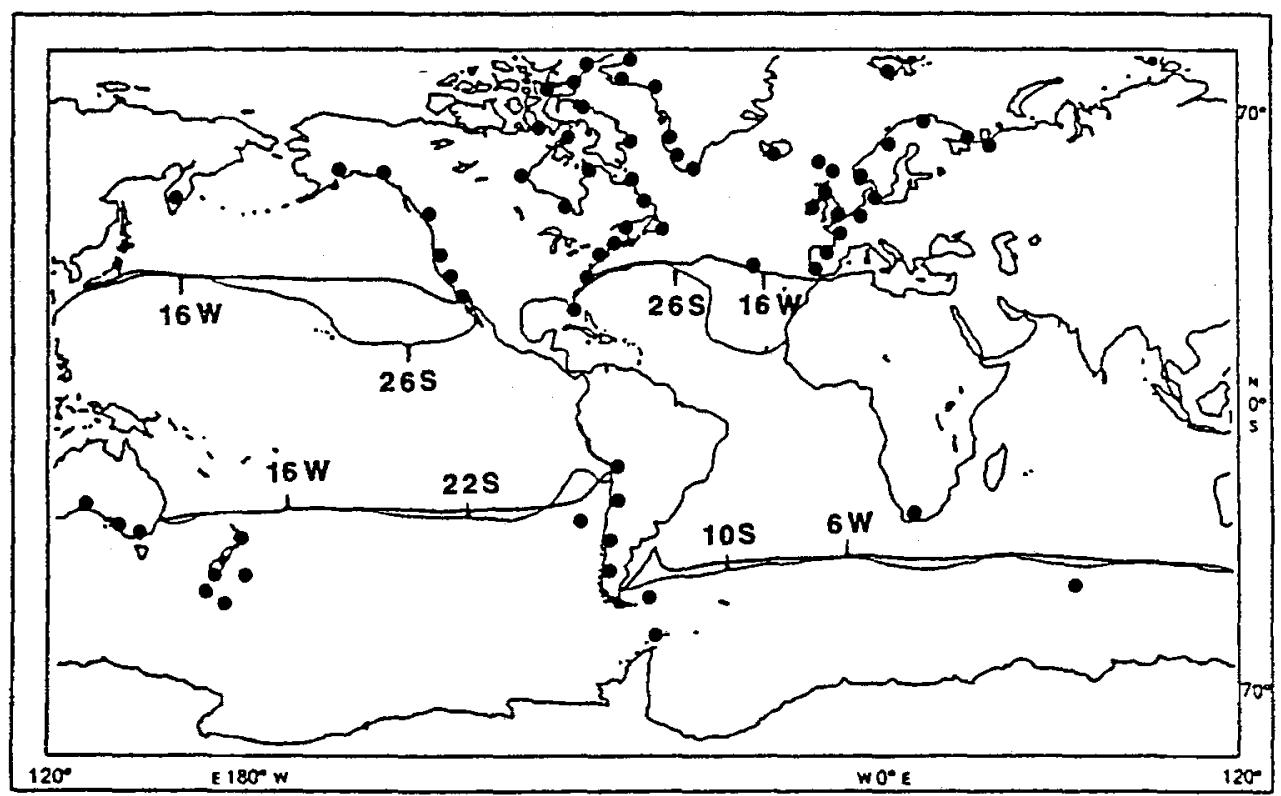

Fig. 22. Distribution of Ulva lactuca. Thick line (W): limiting winter isotherm. Thin line (S): limiting summer isotherm. (Distribution according to Chapman, 1956; Etcheverry, 1983; Hay et al., 1985; Kjellman, 1883; Levring, 1960; Papenfuss, 1964; Pedersen, 1976; Scagel, 1957; Scagel et al., 1989; Seagrief, 1984; South, 1984; South \& Tittley, 1986; Taylor, 1939; Womersley, 1984.)

for reproduction. The distribution in the Southern Hemisphere cannot be explained by the available experimental data.

Bangia atropurpurea, Enteromorpha clathrata, Enteromorpha intestinalis and Eudesme virescens are cosmopolitan species. The distribution pattern of each of these species (not shown) and the high USL's $\left(24,31,28\right.$ and $30^{\circ} \mathrm{C}$, respectively), indicate that these species may have recently crossed the tropical region. The relatively low USL of Bangia atropurpurea $\left(24^{\circ} \mathrm{C}\right)$, seems contradictory, yet the distribution of this species is described for tropical coasts of America (Scagel, 1957; Scagel et al., 1989; Wynne, 1986).

Acknowledgements. The study was supported by the Deutsche Forschungsgemeinschaft. P. M. Pedersen and A. Kristiansen, Copenhagen, provided the opportunity for C. Wiencke to stay on the Arctic station of the University of Copenhagen on Disko Island (Greenland). P. M. Pedersen kindly determined the Chromastrum species. He and A. M. Breeman, University of Groningen, commented on an early draft of this paper. We also thank D. N. Thomas, Bremerhaven, for critically reading the manuscript. C. Langreder gave excellent technical support. This is publication No. 655 of the AlfredWegener-Institut für Polar- und Meeresforschung, Bremerhaven.

\section{LITERATURE CITED}

Asensi, A.O., 1966. Guia para reconocer los generos de algas pardas de la Argentina. Instituto Antartico Argentino, Buenos Aires, $51 \mathrm{pp}$. 
Berry, J. A. \& Raison, J. K., 1981. Responses of macrophytes to temperature. In: Encyclopedia of plant physiology. Ed. by D. L. Lange, P. S. Nobel, L. B. Osmond \& H. Ziegler. 12A, 277-338.

Bliding, C., 1963. A critical survey of European taxa in Ulvales. Part I. Capsosiphon, Percursaria, Blidingia, Enteromorpha. Op. bot., Lund., 1-160.

Bolton, J. J., 1983. Ecoclinal variation in Ectocarpus siliculosus (Phaeophyceae) with respect to temperature growth optima and survival limits. - Mar. Biol. 73, 131-138.

Bolton, J. J. \& Lüning, K., 1982. Optimal growth and maximal survival temperatures of Atlantic Laminaria species (Phaeophyta) in culture. - Mar. Biol. 66, 89-94.

Breeman, A.M., 1988. Relative importance of temperature and other factors in determining geographic boundaries of seaweeds: experimental and phenological evidence. - Helgoländer Meeresunters. 42, 199-241.

Breeman, A. M., 1990. Expected effects of changing seawater temperatures on the geographic distribution of seaweed species. In: Expected effects of climatic change on marine coastal ecosystems. Ed. by J. J. Beukema, W. J. Wolff \& J. J. W. M. Brouns. Kluwer, Dordrecht, 69-76.

Cambridge, M. L., Breeman, A. M., Kraak, S. \& Hoek, C. van den, 1987. Temperature responses of tropical to warm temperate Cladophora species in relation to their distribution in the North Atlantic Ocean. - Helgoländer Meeresunters. 41, 329-354.

Chapman, V. J., 1956. The marine algae of New Zealand. Part I: Myxophyceae and Chlorophyceae. - J. Linn. Soc. (Bot.) 55, 333-501.

Clayton, M. N. \& Wiencke, C., 1986. Techniques and equipment for culturing Antarctic benthic marine algae, and for preparing specimens for electron microscopy. - Ser. Cient. INACH 34, 93-97.

Dawes, C. J., 1974. Marine algae of the west coast of Florida. Univ. of Miami Press, Coral Gables, $201 \mathrm{pp}$.

Dieck, I. tom, 1989. Vergleichende Untersuchungen zur Ökophysiologie und Kreuzbarkeit innerhalb der digitalen Sektion der Gattung Laminaria Lamouroux (Phaeophyceae). Diss., Univ. Hamburg, $168 \mathrm{pp}$.

Dieck, I. tom (Bartsch), 1992a. Circannual growth rhythm and photoperiodic sorus induction in the kelp Laminaria setchellii (Phaeophyta). - J. Phycol. 27, 341-350.

Dieck, I. tom (Bartsch), 1992b. North Pacific and North Atlantic digitate Laminaria species (Phaeophyta): hybridization experiments and temperature responses. - Phycologia 31, 147-163.

Dieck, I. tom (Bartsch), 1993. Temperature tolerance and survival in darkness of kelp gametophytes (Laminariales, Phaeophyta). - Mar. Ecol. Prog. Ser. (in press).

Egan, B., Gracia-Ezquivel, Z., Brinkhuis, B. H. \& Yarish, C., 1990. Genetics of morphology and growth in Laminaria from the North Atlantic Ocean-implications for biogeography. In: Evolutionary biogeography of the marine algae of the North Atlantic. Ed. by D. J. Garbary \& G. R. South. Springer, Berlin, 147-172.

Etcheverry, D. H., 1983. Algas bentónicas de la Antártica Chilena. Instituto Antartico Chileno - Ser. Cient. INACH 30, 97-124.

Fortes, M.D. \& Lüning, K., 1980. Growth rates of North Sea macroalgae in relation to temperature, irradiance and photoperiod. - Helgoländer Meeresunters. 34, 15-29.

Gabrielson, P.W., Scagel, R. F. \& Widdowson, T. B, 1989. Keys to the benthic marine algae and seagrasses of British Columbia, Southeast Alaska, Washington and Oregon. Univ. of British Columbia, Vanvcouver, $187 \mathrm{pp}$.

Graham, J.M. \& Graham, L. E., 1987. Growth and reproduction of Bangia atropurpurea (Roth) C. AG. (Rhodophyta) from the Laurentian Great Lakes. - Aquat. Bot. 28, 317-331.

Grant-Meckie, J.A., 1979. Cretaceous-recent plate tectonic history and palaeooceanographic development of the Southern Hemisphere. - Inf. Ser. Dep. scient. ind. Res. NZ, 137, (1) 27-42.

Guiry, M. D., 1982. Devaleraea, a new genus of the Palmariaceae (Rhodophyta) in the North Atlantic and North Pacific. - J. mar. biol. Ass. U.K. 62, 1-13.

Guiry, M.D., Tripodi, G. \& Lüning, K., 1987. Biosystematics, genetics and upper temperature tolerance of Gigartina teedii (Rhodophyta) from the Atlantic and Mediterranean. - Helgoländer Meeresunters. 41, 283-295.

Hay, C.H., Adams, N. M. \& Parsons, M.J., 1985. The marine algae of the sub-antarctic islands of New Zealand. - Misc. Ser. Nat. Mus. N. Z. 11, 1-70.

Hempel, G., 1987. Die Polarmeere - ein biologischer Vergleich. - Polarforschung 57, 173-189. 
Hoek, C. van den, 1982a. The distribution of benthic marine algae in relation to the temperature regulation of their life histories. - Biol. J. Linn. Soc. 18, 81-144.

Hoek, C. van den, 1982b. Phytogeographic distribution groups of benthic marine algae in the North Atlantic Ocean. A review from the experimental evidence from life histories. - Helgoländer Meeresunters. 35, 153-214.

Hoek, C. van den, 1984. Algen. Thieme, Stuttgart, $481 \mathrm{pp}$.

Hoek, C. van den \& Breeman, A. M., 1989. Seaweed biogeography of the North Atlantic: Where are we now?. In: Evolutionary biogeography of the marine algae of the North Atlantic. Ed. by D.J. Garbary \& G. R. South. Springer, Berlin, 57-86.

Kjellman, F. R., 1883. The algae of the Arctic Sea. - K. svenska Vetenskaps-Akad. Handl. 20, 1-350.

Kornmann, P., 1962. Die Entwicklung von Chordaria flagelliformis. - Helgoländer wiss. Meeresunters. $8,276-279$.

Kornmann, P., 1964. Der Lebenszyklus von Acrosiphonia arcta. - Helgoländer wiss. Meeresunters. $11,110-117$.

Kornmann, P., 1966a. Wachstum und Zellteilung bei Urospora. - Helgoländer wiss. Meeresunters. $13,73-83$.

Kornmann, P., 1966b. Hormiscia neu definiert. - Helgoländer wiss. Meeresunters. 13, 408-425.

Kornmann, P., 1972. Ein Beitrag zur Taxonomie der Gattung Chaetomorpha (Cladophorales, Chlorophyta). - Helgoländer wiss. Meeresunters. 23, 1-31.

Kornmann, P. \& Sahling, P.-H., 1983. Meeresalgen von Helgoland. Biologische Anstalt Helgoland, Hamburg, 289 pp. (Veränd. Neudr. von Helgoländer wiss. Meeresunters. 29, 1-289, 1977.)

Lamb, I. M. \& Zimmermann, M. H., 1977. Benthic marine algae of the Antarctic Peninsula. - Antarct. Res. Ser. 23, 129-229.

Levring, T., 1945. Marine algae from some Antarctic and Subantarctic Islands. - Lunds Univ. Arskr. (N. F. Avd. 2) 41, 1-36.

Levring, T., 1960. Contribution to the marine algal flora of Chile. - Lunds Univ. Årsskr. (N. F. Avd. 2) $56,1-85$.

Lindauer, V.W., Chapman, V.J. \& Aiken, M., 1961. The marine algae of New Zealand. II. Phaeophyceae. - Nova Hedwigia 3, 129-350.

Lobban, C.S., Harrison, P.J. \& Duncan, M.J., 1985. The physiological ecology of the seaweeds. Cambridge Univ. Press, Cambridge, $242 \mathrm{pp}$.

Lokhorst, G.M. \& Trask, B.J., 1981. Taxonomic studies on Urospora (Acrosiphoniales, Chlorophyceae) in Western Europe. - Acta bot, néerl. 30, 353-431.

Lüning, K., 1981. Photomorphogenesis of reproduction in marine macroalgae. - Ber. dt. bot. Ges. 94, $401-417$.

Lüning, K., 1984. Temperature tolerance and biogeography of seaweeds: The marine algal flora of Helgoland (North Sea) as an example. - Helgoländer Meeresunters. 38, 305-317.

Lüning, K., 1985. Meeresbotanik. Thieme, Stuttgart, 375 pp.

Lüning, K., 1990. Seaweeds. Wiley, New York, 527 pp.

Lüning, K., 1991. Circannual growth rhythm in a brown alga, Pterygophora californica. - Botanica Acta 104, 157-162.

Lüning, K. \& Dieck, I. tom, 1989. The distribution and evolution of the Laminariales: North PacificAtlantic relationships. In: Evolutionary biogeography of the marine algae of the North Atlantic. Ed. by D. J. Garbary \& G. R. South. Springer, Berlin, 187-204.

Lüning, K. \& Freshwater, W., 1988. Temperature tolerance of Northeast Pacific marine algae. - J. Phycol. 24, 310-315.

Meer, J. P. van der, 1981. The life history of Halosaccion ramentaceum. - Can. J. Bot. 59, 433-436.

Müller, D.G. \& Lüthe, N.M., 1981. Hormonal interaction in sexual reproduction of Desmarestia aculeata (Phaeophyceae). - Br. J. Phycol. 16, 351-356.

Müller, D. G. \& Stache, B., 1989. Life history studies on Pilayella littoralis (L.) Kjellman (Phaeophyceae, Ectocarpales) of different geographical origin. - Botanica mar. 32, 71-78.

Novaczek, I., Breeman, A.M. \& Hoek, C. van den, 1989. Thermal tolerance of Stypocaulon scoparium (Phaeophyta, Sphacelariales) from eastern and western shores of the North Atlantic Ocean. - Helgoländer Meeresunters. 43, 183-193.

Novaczek, I. \& Breeman, A. M., 1990. Thermal ecotypes of amphi-Atlantic algae. II. Cold-temperate species (Furcellaria lumbricalis and Polyides rotundus). - Helgoländer Meeresunters. 44, 475-485. 
Novaczek, I., Lubbers, G. W. \& Breeman, A. M., 1990. Thermal ecotypes of amphi-Atlantic algae. I. Algae of Arctic to cold-temperate distribution (Chaetomorpha melagonium, Devaleraea ramentacea and Phycodrys rubens). - Helgoländer Meeresunters. 44, 459-474.

Orfanidis, S., 1992. Light requirements for growth of six shade-acclimated Mediterranean macroalgae. - Mar. Biol. 112, 511-515.

Papenfuss, G. F., 1964. Catalogue and bibliography of Antarctic and Subantarctic benthic marine algae. - Antarct. Res. Ser. 1, 1-76.

Pedersen, P.M., 1976. Marine benthic algae from southernmost Greenland. - Meddr Grønland 199, 1-79.

Peters, A.F., 1987. Reproduction and sexuality in the Chordariales (Phaeophyceae). A review of culture studies. - Prog. phycol. Res. 5, 223-263.

Peters, A.F. \& Breeman, A.M., 1992. Temperature responses of disjunct temperate brown algae indicate long-distance dispersal of microthalli across the tropics. - J. Phycol. 28, 428-438.

Richardson, N. \& Dixon, P. S., 1968. Life history of Bangia fuscopurpurea (Dillw.) Lyngb. in culture. Nature, Lond. $218,496-497$.

Ricker, R.W., 1987. Taxonomy and biogeography of Macquarie Island seaweeds. British Museum (Natural History), London, $344 \mathrm{pp}$.

Rueness, J. \& Tanager, T., 1984. Growth in culture of four red algae from Norway with potential for mariculture. - Hydrobiologia 116-117, 303-307.

Santelices, B. \& Abbott, I. A., 1978. New records of marine algae from Chile and their effect on phytogeography. - Phycologia 17, 213-222.

Scagel, R.F., 1957. An annotated bibliography of the marine algae of British Columbia and northern Washington including keys to genera. - Bull. natn. Mus. Can. 150, 1-289.

Scagel, R.F., Gabrielson, P.W., Garbary, D.D., Golden, L., Hawkes, M. W., Lindstrom, S. C., Oliveira, J.C. \& Widdowson, T.B., 1989. A synopsis of the benthic marine algae of British Columbia, Southeast Alaska, Washington and Oregon. Univ. of British Columbia, Vancouver, $532 \mathrm{pp}$.

Scarlato, O.A., 1977. Bivalve molluscs and temperature as an agent determining their geographical distribution. - Malacologia 16, 247-250.

Schneider, C. W. \& Searles, R. B., 1991. Seaweeds of the Southeastern United States: Cape Hatteras to Cape Canaveral. Duke Univ. Press, Durham, N. C., 553 pp.

Schreiber, E., 1932. Entwicklungsgeschichte und systematische Stellung der Desmarestiaceen. - Z. Bot. 25, 561-582.

Seagrief, S. C., 1984. A catalogue of South African green, brown and red marine algae. - Mem. bot. Surv. S. A. $47,1-72$.

Skottsberg, C., 1907. Zur Kenntnis der subantarktischen und antarktischen Meeresalgen, I. Phaeophyceen. In: Ergebnisse der Schwedischen Südpolarexpedition 1901-1903. Ed. by O. Nordenskjöld. Asher, Berlin, 172 pp.

Skottsberg, C., 1921. Botanische Ergebnisse der schwedischen Expedition nach Patagonien und dem Feuerlande 1907-1909, VIII. Marine Algen 1. Phaeophyceae. - K. svenska Vetensk, Akad. Handl. 61,1-56.

South, G. R., 1984. A checklist of marine algae of eastern Canada. Second revision. - Can. J. Bot. 62, $680-704$.

South, G. R. \& Tittley, I., 1986. A checklist and distribution index of the benthic marine algae of the North Atlantic Ocean. British Museum (Natural History), London, $76 \mathrm{pp}$.

Taylor, W. R., 1939. Algae collected by the "Hassler", "Albatross" and Schmitt Expeditions II. Marine algae from Uruguay, Argentina, the Falkland Islands, and the Strait of Magellan. - Pap. Mich. Acad. Sci. 24, 127-164.

Tseng, C. K, (Ed.), 1983. Common seaweeds of China. Science Press, Beijing, 316 pp.

Thiede, J., 1986. Zur geologischen Geschichte der Polarmeere und ihrer Wassermassen. Geol, Paläontol. Inst. Univ., Kiel, $312 \mathrm{pp}$.

Wagner, H.P. \& Zaneveld, J.S., 1988. The Xanthophyceae and Chlorophyceae of the western Ross Sea, Victoria Land, Antarctica and Macquarie Island collected under the direction of Prof. Dr. J.S. Zaneveld (1963-1967). - Blumea 33, 141-180.

Wiencke, C. \& Dieck, I. tom 1989. Temperature requirements for growth and temperature tolerance of macroalgae endemic to the Antarctic region. - Mar. Ecol. Prog. Ser. 54, 189-197. 
Wiencke, C. \& Dieck, I. tom 1990. Temperature requirements for growth and survival of macroalgae from Southern Chile. - Mar. Ecol. Prog. Ser. 59, 157-170.

Womersley, H.B.S., 1984. The marine benthic flora of Southern Australia, Part I. South Australia Govt. Print. Div., Adelaide, $329 \mathrm{pp}$.

Wynne, M.J., 1986. A checklist of benthic marine algae of the tropical and subtropical western Atlantic. - Can. J. Bot. 64, 2239-2281.

Yarish, C., Breeman, A. M. \& Hoek, C. van den, 1986. Survival strategies and temperature responses of seaweeds belonging to different biogeographic distribution groups. - Botanica mar. 24, 215-230.

Yarish, C., Kirkman, H. \& Lüning, K., 1987. Lethal exposure times and preconditioning to upper temperature limits of some temperate North Atlantic red algae. - Helgoländer Meeresunters. 41, $323-327$. 